\title{
The tropospheric distribution and budget of ethane
}

\author{
J. Rudolph \\ Institut für Atmosphärische Chemie, Forschungszentrum Jülich, GmbH, Jülich, Germany
}

\begin{abstract}
From about 1500 measurements of ethane in the remote troposphere the longitudinally and vertically averaged latitudinal and seasonal variability of ethane was derived. To improve the data coverage, several data sets from literature were included. There are only very few data sets available for the southern hemisphere. Nevertheless, the uncertainty of the average seasonal/latitudinal ethane profile is estimated to less than $30 \%$. The global annually averaged ethane mixing ratio is $860 \mathrm{ppt}$. There is a strong interhemispheric gradient with an average north/south ratio of 3.5 . Within the northern hemisphere there is an average gradient from the highest annual mean value of $2500 \mathrm{ppt}$ around $65^{\circ} \mathrm{N}$ to about $600 \mathrm{ppt}$ at the equator. In the southern hemisphere there is only a small gradient at low latitudes and at middle and high southern latitudes no significant gradient can be seen. In both hemispheres a significant seasonal cycle with highest mixing ratios in late winter is observed. The ethane source strength needed to balance the atmospheric budget of ethane is estimated to $15.5 \mathrm{Tg} / \mathrm{yr}$, with most of the emissions in the northern hemisphere. An independent estimate of the sources indicate that most of the emissions are due to natural gas losses $(6 \mathrm{Tg} / \mathrm{yr})$ and biomass burning $(6.4 \mathrm{Tg} / \mathrm{yr})$. This is also compatible with the latitudinal and seasonal variation of the atmospheric ethane removal rates. However, these estimates have substantial uncertainties and it should be noted that the role of the biosphere for the atmospheric budget of ethane is presently not understood.
\end{abstract}

\section{Introduction}

Ethane is the second most abundant organic trace gas in the background troposphere [cf. Rudolph, 1988; Kanakidou et al., 1991]. With mixing ratios ranging from a fraction of a part per billion to a few parts per billion [Rudolph and Ehhalt, 1981; Rudolph, 1988; Koppmann et al., 1992; Ehhalt et al., 1991; Ehhalt, 1992], it is roughly 3 orders of magnitude less abundant than methane. However, because of its higher reactivity and the possibility of forming more complex intermediates (e.g., acetaldehyde, peroxyacetyl nitrate, and acetic acid), the oxidation of ethane is important to tropospheric chemistry. Thus the existence of ethane in the background troposphere opens up chemical pathways in atmospheric chemistry which would not be accessible from methane oxidation alone [cf. Ehhalt and Rudolph, 1984].

Ethane can also serve to test predictions of atmospheric transport and chemistry models and to check the strength and geographic distribution of sources of atmospheric trace gases. The tropospheric lifetime of a few months [Rudolph and Ehhalt, 1981] is long enough to reduce the random variability in the mixing ratios in the background troposphere to an acceptable level but short enough to allow pronounced seasonal cycles and latitudinal gradients.

Our understanding of the distribution of ethane in the remote troposphere has improved considerably during the past 15 years. There have been several series of measurements of light nonmethane hydrocarbons, including ethane, in the remote troposphere. These measurements cover seasonal cycles [Singh and Salas, 1982; Blake and Rowland, 1986; Bonsang et al., 1990; Ehhalt et al., 1991; Rudolph et

Copyright 1995 by the American Geophysical Union.

Paper number 95JD00693.

0148-0227/95/95JD-00693\$05.00 al., 1989a, 1992a; Jobson et al., 1994], latitudinal distributions [Rudolph et al., 1979, 1982a, 1984; Rudolph and Ehhalt, 1981; Singh and Salas, 1982; Bonsang and Lambert, 1985; Singh et al., 1988; Rudolph, 1988; Koppmann et al., 1990, 1992], and vertical profiles [Rudolph et al., 1980, 1981a, 1982b; Singh et al., 1988; Rudolph, 1988; Blake et al., 1992, 1994]. Still, there are substantial gaps in our understanding of the distribution of ethane in the remote troposphere.

In this paper an overview over the latitudinal and seasonal variation of ethane in the background troposphere will be presented. This is mainly based on measurements made by the laboratory in Jülich between 1980 and 1992, supplemented by several data sets from the literature in order to improve the data coverage.

\section{Measurements}

Air was collected in stainless steel canisters of $0.5-2 \mathrm{dm}^{3}$ volume and the samples were analyzed later in the laboratory in Jülich. Onboard airplanes the samples were always taken from a continuously flushed stainless steel inlet line and either collected at ambient pressure or pressurized with a metal bellows pump. Details of the sample collection procedures are described by Rudolph et al. [1982b] and Rudolph [1988]. Several test series confirmed that storage of the samples did not cause any detectable change in the ethane concentrations, even for storage times of several months. The measurements of ethane and other nonmethane hydrocarbons were made by gas chromatography in combination with a cryogenic preconcentration step. In most cases a micropacked column ( $7 \mathrm{~m}$ length, ID $0.8 \mathrm{~mm}$, stainless steel packed with Porapak QS) was used for the separation and a flame ionization detector (FID) for detection. Details of the analytical procedure, sample canisters, etc., are given 


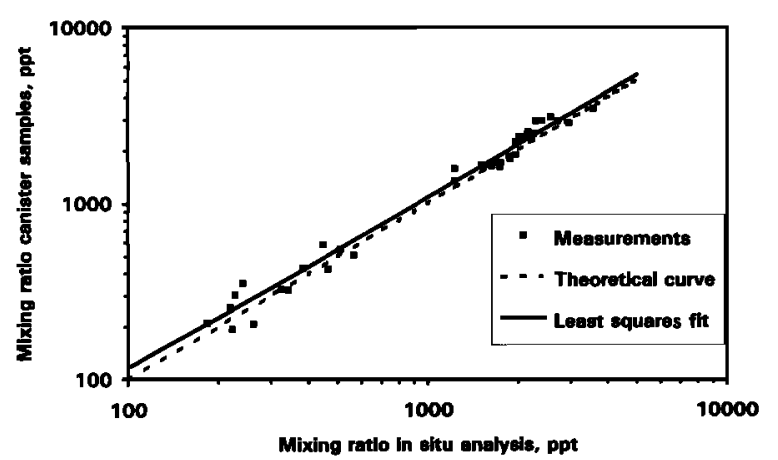

Figure 1. Comparison of ethane measurements made by canister sampling and in situ analysis during a ship cruise of FS Polarstern over the Atlantic in 1987.

by Rudolph and Jebsen [1983], Rudolph and Khedim [1985], and Rudolph et al. [1981b, 1986, 1989a, b, 1990, 1992b]. The ethane mixing ratios were determined by comparing the peak areas or heights of the sample chromatograms with those of a reference air of known ethane concentration. The ethane concentration in the reference air tanks (high-pressure cylinders of 10 or $40 \mathrm{dm}^{3}$ volume and $20-100$ bar pressure) was always similar to the ambient mixing ratios (1-5 ppb). The ethane concentration in the primary reference air tank was determined by comparison with mixtures of a few parts per billion in synthetic air which were prepared from pure (>99.5\%) ethane by a two- or three-step static dilution procedure. The reproducibility of the dilution procedure is about $10 \%$ and the estimated accuracy is better than $20 \%$. The ethane mixing ratio in the primary reference air tank was checked in irregular intervals (between 6 months and several years) by a comparison with freshly prepared mixtures of ethane in synthetic air. No variations exceeding the precision of the measurements were found. For various purposes (e.g., in situ analysis, instrument tests), secondary reference air tanks were used (ambient air collected cryogenically in 10 or $40 \mathrm{dm}^{3}$ cylinders at pressures between 50 bar and 150 bar). After storage for several weeks they were calibrated by at least five measurements relative to the primary reference air and checked for stability by further measurements after a few months. Depending on the use of these secondary reference gases, the comparison was repeated several times in intervals between a few months and 2 years. Reference air tanks used in field campaigns were always checked before and after the campaign. Within the uncertainty of the measurements no changes in the ethane concentration of these secondary standards could be detected.

The ethane concentrations were always at least 1 order of magnitude above the detection limit of 10-20 ppt. The reproducibility of the measurements is better than $10 \%$, the estimated accuracy, including calibration errors, better than $20 \%$. The Jülich ethane calibration was compared several times with other calibrations, either during field measurements with other groups or as part of intercomparison experiments (cf. Carsey [1987], Rudolph et al. [1992b], and E. Apel, private communication (1994) on the results of the "International Nonmethane Hydrocarbon Intercomparison Experiment, Phase 2"). In all cases the Jülich ethane calibration agreed within the accuracy of $20 \%$ with the estimated "correct" value of the intercomparison, in most cases the agreement was better than $10 \%$.
During some of the shipbased campaigns the measurements were made in-situ with an instrument on board the ship by slightly different gas chromatographic techniques [Rudolph and Johnen, 1990; Koppmann et al., 1992]. During a ship cruise over the Atlantic in 1987 whole air samples were collected parallel to in-situ measurements. In Figure 1 the results of the laboratory analysis of the whole air samples are compared with the in situ measurements. There are a few small deviations from the ideal behavior, but they are well within the uncertainty of the measurements. Nevertheless, the deviations are occasionally somewhat larger than expected from the reproducibility of the measurements alone. However, the two types of measurements were made with different gas chromatographs, different types of separation columns, and in completely different environments (shipboard operation in a container compared to an air conditioned laboratory). Different reference gases were used, but they were based on the same calibration. Thus the differences between two measurement series give a realistic idea of all errors which result from the use of different gas chromatographic methods which are based on a common calibration. The general agreement within less than $10 \%$ proves the quality of the measurements made by the two methods.

\section{Data Set}

Table 1 lists the various measurement series and the average of the measured ethane mixing ratios for the most important parts of these campaigns. Most of the measurements were made onboard ships and airplanes, but several measurement series were also made at remote stations. Not included are measurements in the vicinity of strong industrial or urban hydrocarbon sources. Measurements from the same flight were combined over the whole altitude range if they were made within a latitude-longitude grid of less than $10^{\circ} \times 10^{\circ}$. Not included are measurements from the tropopause region and the stratosphere. Shipboard measurements were, in general, averaged for intervals of $10^{\circ}$ latitude, only in regions with strong gradients (e.g., the Intertropical Convergence Zone (ITCZ); smaller intervals were used if the data density was sufficient (more than 10 data points for $10^{\circ}$ latitude). In the case of a lower data coverage, average values for larger latitude intervals are given if the data showed no significant gradient within this latitude range. For remote stations the seasonal cycle was directly determined from a fit to a sinusoidal curve with a period of 12 months if the data coverage was sufficient; otherwise monthly means are calculated. All ethane mixing ratios given in Table 1 are averages from at least five data points, in most cases from more than 10. The total number of measurements is around 1500.

To improve the data coverage for regions and seasons where the Jülich data are sparse, several data sets from the literature were included in the data analysis [Cronn and Robinson, 1979; Singh and Salas, 1982; Rasmussen and Khalil, 1982, 1983; Greenberg and Zimmerman, 1984; Hov et al., 1984, 1989; Bonsang and Lambert, 1985; Tille et al., 1985; Blake and Rowland, 1986; Aikin et al., 1987; Rinsland et al., 1987; Singh et al., 1988; Schmitt, 1990; Lightman et al., 1990; Bonsang et al., 1990, 1991, 1994; Greenberg et al., 1990, 1992; Ehhalt et al., 1991; Blake et al., 1994]. For ethane this can be done without risk of a significant bias due 
to calibration errors and measurement uncertainties. The nonmethane hydrocarbon (NMHC) intercomparisons, made during the last 8 years, gave for ethane results which agreed for nearly all laboratories within better than 20\% [Carsey, 1987; Rudolph et al., 1982b; E. Apel, private communication, 1994]. The data were taken from tables or figures in the references and averaged following the same procedure as explained above. This resulted in nearly 70 additional mean values for ethane concentrations at different latitudes and seasons.

\section{Calculation of the Global Distribution}

In spite of the substantial available data set, the overall data coverage is by far not complete and a fair amount of interpolation and averaging is needed to derive a global picture of the tropospheric ethane distribution. For an atmospheric trace gas with a lifetime of a few months we can expect only small longitudinal variations and weak vertical gradients in the background troposphere. Indeed, except for measurements which are directly influenced by the vicinity of strong sources, the measured vertical profiles of ethane exhibit only very small gradients [cf. Rudolph et al., 1980, 1982a; Ehhalt and Rudolph, 1984; Ehhalt et al., 1985, 1986; Singh et al., 1988; Blake et al., 1992, 1994]. As an example, the average profile derived from the two-dimensional distribution measured during the STRATOZ III flights [Rudolph, 1988 ] is shown in Figure 2. Within the boundary layer, the ethane mixing ratios are about $10 \%$ higher than above; in the free troposphere the ethane concentrations show no systematic gradient within an uncertainty of less than $5 \%$. Consequently, the error which results from combining ethane measurements from different altitudes is, on average, well below $10 \%$. There are no systematic studies of the longitudinal gradients of the ethane mixing ratios. In general, it is assumed that the longitudinal variations are small compared to seasonal and latitudinal changes [Hough, 1991; Kanakidou et al., 1991; Isaksen et al., 1985]. Model calculations of the longitudinal ethane distribution at middle northern latitudes with a zonal channel model showed only marginal longitudinal gradients (F. Rohrer, private communication, 1993). Furthermore, the ethane measurements made at different longitudes but in the same latitude belt fit within their uncertainties into the same seasonal pattern (see example in Figure 3). Therefore it seems reasonable to combine ethane measurements from different longitudes although the present knowledge about the longitudinal distribution of ethane is still limited. The ethane data set includes measurements from a period of nearly 15 years. There are indications for the existence of a secular trend of the ethane concentrations in the troposphere. Ehhalt et al. [1991] report an increase rate of $0.85 \% / y r$ for middle northern latitudes and Rudolph et al. [1992a] an increase rate of $0.5 \% / y r$ for high southern latitudes. Since all corrections would be within a range of \pm $5 \%$ from the mean, and the absolute magnitude of the trend is rather uncertain for the different latitude bands and seasons, a correction of the data from different years is not necessary.

The latitudinal and seasonal dependence of the tropospheric ethane mixing ratios is derived by combining all data from a latitude band of typically $10^{\circ}-20^{\circ}$. The width of the latitude band was selected according to the available number of data points in the intervals and the steepness of the latitudinal gradient. This was done for the latitudes between $85^{\circ} \mathrm{N}$ and $85^{\circ} \mathrm{S}$ at steps of $5^{\circ}$ latitude. A sinusoidal curve was fitted to each of the resulting data sets of ethane mixing ratios as a function of calendar month. A 1-year period was prescribed for the function; amplitude, mean, and phase were calculated by a least squares fit. An example is shown in Figure 3. From each of the seasonal cycles for the different latitude bands the average ethane mixing ratio was calculated for each calender month and the results combined to a latitude-season dependence of the ethane mixing ratio. The resulting 1 month times $5^{\circ}$ latitude distribution was smoothed once by a second-order Chebyshev polynomial. The resulting latitude-season dependence of the longitudinally averaged tropospheric ethane mixing ratio is shown in Figure 4. The sine fits have typical errors of 5-10\% for the mean value, about $20-30 \%$ for the amplitude, and about 0.5 months for the phase. From this we estimate that this altitudinally and longitudinally averaged tropospheric ethane distribution describes the average situation within an uncertainty of about $30 \%$.

\section{Discussion \\ Comparison With Recent Literature Data}

To obtain an estimate of the representativity of the global ethane distribution, one can compare it with ethane measurements which have not been included in the data set. Quite extensive measurement series of ethane in the troposphere have recently been presented by Donahue and Prinn [1993], Jobson et al. [1994], Lindskog and Moldanova [1994], and Blake et al. [1995].

In Figures $5 \mathrm{a}$ and $5 \mathrm{~b}$ the longitudinally averaged seasonal variations for $50^{\circ} \mathrm{N}$ and $57.5^{\circ} \mathrm{N}$, respectively, are compared with the measured seasonal cycles from Jobson et al. [1994] and Lindskog and Moldanova [1995]. The agreement is very good, always within the estimated uncertainty of $30 \%$. On average, a difference of $12 \%$ is found for the measurements in Canada and $6.5 \%$ for those in Sweden. The slightly larger ethane mixing ratios found by Jobson et al. [1994] suggest a minor impact of regional NMHC sources which is supported by the simultaneous observations of substantial levels (up to several hundred parts per trillion) of more reactive alkanes such as $i$-pentane and $n$-pentane; but also small differences in the absolute calibrations and small longitudinal variations cannot be ruled out. The measurements by Lindskog and Moldanova [1995] cover only a period of slightly more than 1 year and the measurements show a standard deviation of 20-30\%; the observed small differences therefore have little significance.

In Figures $6 \mathrm{a}$ and $6 \mathrm{~b}$ the longitudinally averaged latitudinal profiles are compared with the results of measurements published by Blake et al. [1995] and Donahue and Prinn [1993], respectively. Although the observations made at different longitudes show some variability, the mean agrees very well with our longitudinal average for the month of observation. The comparison with the measurements of Donahue and Prinn [1993] shows some minor differences. Although the agreement south of $5^{\circ} \mathrm{S}$ and north of $5^{\circ} \mathrm{N}$ is very good, the shape of the gradient at the equator differs significantly. The measurements by Donahue and Prinn [1993] show a stepwise change at $5^{\circ} \mathrm{S}$, whereas the average latitudinal profile for this month (September) shows a more gradual change. The longitudinally averaged latitudinal pro- 
Table 1. Average Ethane Mixing Ratios in Different Regions and Months Measured by Jülich

\begin{tabular}{|c|c|c|c|c|c|}
\hline Region & Platform & Latitude & Month & $\begin{array}{l}\text { Altitude, } \\
\text { km* }\end{array}$ & $\underset{\mathrm{ppt}^{\dagger}}{\text { Mixing Ratio, }}$ \\
\hline Atlantic & ship & $30^{\circ} \mathrm{S}-55^{\circ} \mathrm{S}$ & January & $\mathbf{0}$ & $340 \pm 21$ \\
\hline Atlantic & ship & $55^{\circ} \mathrm{S}-75^{\circ} \mathrm{S}$ & January & 0 & $350 \pm 50$ \\
\hline Atlantic & ship & $35^{\circ} \mathrm{N}-50^{\circ} \mathrm{N}$ & Jan./Feb. & $\mathbf{0}$ & $2270 \pm 130$ \\
\hline Atlantic & ship & $20^{\circ} \mathrm{N}-30^{\circ} \mathrm{N}$ & $\operatorname{Jan} . / F e b$. & $\mathbf{0}$ & $1920 \pm 180$ \\
\hline Atlantic & ship & $5^{\circ} \mathrm{N}-10^{\circ} \mathrm{N}$ & Jan./Feb. & 0 & $1700 \pm 460$ \\
\hline Atlantic & ship & $2^{\circ} \mathrm{S}-5^{\circ} \mathrm{N}$ & Jan./Feb. & $\mathbf{0}$ & $670 \pm 60$ \\
\hline Norway & airplane & $68^{\circ} \mathrm{N}$ & March & $2.5-10$ & $3700 \pm 300$ \\
\hline Central Europe & airplane & $51^{\circ} \mathrm{N}$ & March & $2.5-4.5$ & $3800 \pm 600$ \\
\hline Norway & airplane & $68^{\circ} \mathbf{N}$ & March & $2-5$ & $1650 \pm 240$ \\
\hline Atlantic & ship & $30^{\circ} \mathrm{N}-45^{\circ} \mathrm{N}$ & March & $\mathbf{0}$ & $3500 \pm 100$ \\
\hline Atlantic & ship & $10^{\circ} \mathrm{N}-30^{\circ} \mathrm{N}$ & March & $\mathbf{0}$ & $3000 \pm 300$ \\
\hline Atlantic & ship & $0^{\circ} \mathrm{N}-10^{\circ} \mathrm{N}$ & March & $\mathbf{0}$ & $640 \pm 140$ \\
\hline Atlantic & ship & $0^{\circ} \mathrm{N}-10^{\circ} \mathrm{S}$ & March & $\mathbf{0}$ & $300 \pm 100$ \\
\hline Atlantic & ship & $10^{\circ} \mathrm{S}-30^{\circ} \mathrm{S}$ & March & $\mathbf{0}$ & $420 \pm 50$ \\
\hline Atlantic & ship & $30^{\circ} \mathrm{N}-45^{\circ} \mathrm{N}$ & March & $\mathbf{0}$ & $2100 \pm 500$ \\
\hline Atlantic & ship & $10^{\circ} \mathrm{N}-30^{\circ} \mathrm{N}$ & March & $\mathbf{0}$ & $1800 \pm 600$ \\
\hline Atlantic & ship & $0^{\circ} \mathrm{N}-10^{\circ} \mathrm{N}$ & March & $\mathbf{0}$ & $1500 \pm 700$ \\
\hline Atlantic & ship & $0^{\circ} \mathrm{N}-10^{\circ} \mathrm{S}$ & March & $\mathbf{0}$ & $460 \pm 200$ \\
\hline Atlantic & ship & $10^{\circ} \mathrm{S}-30^{\circ} \mathrm{S}$ & March & 0 & $460 \pm 150$ \\
\hline Western Europe & airplane & $65^{\circ} \mathrm{N}$ & March & $1-9$ & $2900 \pm 100$ \\
\hline Western Europe & airplane & $55^{\circ} \mathrm{N}-60^{\circ} \mathrm{N}$ & March & $1-9$ & $2300 \pm 200$ \\
\hline Western Europe & airplane & $40^{\circ} \mathrm{N}-55^{\circ} \mathrm{N}$ & March & $1-10$ & $2400 \pm 170$ \\
\hline West Coast Africa & airplane & $15^{\circ} \mathrm{N}-30^{\circ} \mathrm{N}$ & March & $1-11$ & $1200 \pm 140$ \\
\hline West Coast Africa & airplane & $5^{\circ} \mathrm{N}-15^{\circ} \mathrm{N}$ & March & $1-11$ & $1090 \pm 70$ \\
\hline West Coast Africa & airplane & $0^{\circ} \mathrm{N}-5^{\circ} \mathrm{N}$ & March & $1-11$ & $640 \pm 100$ \\
\hline France & airplane & $45^{\circ} \mathrm{N}$ & March & $1-10$ & $2460 \pm 190$ \\
\hline Atlantic & ship & $40^{\circ} \mathrm{N}-50^{\circ} \mathrm{N}$ & March & $\mathbf{0}$ & $2090 \pm 24$ \\
\hline Atlantic & ship & $30^{\circ} \mathrm{N}-40^{\circ} \mathrm{N}$ & March & 0 & $2330 \pm 45$ \\
\hline Atlantic & ship & $20^{\circ} \mathrm{N}-30^{\circ} \mathrm{N}$ & March & $\mathbf{0}$ & $1540 \pm 150$ \\
\hline Atlantic & ship & $10^{\circ} \mathrm{N}-20^{\circ} \mathrm{N}$ & March & $\mathbf{0}$ & $1410 \pm 50$ \\
\hline Atlantic & ship & $5^{\circ} \mathrm{N}-10^{\circ} \mathrm{N}$ & April & $\mathbf{0}$ & $1680 \pm 30$ \\
\hline Atlantic & ship & $0^{\circ} \mathrm{N}-5^{\circ} \mathrm{N}$ & April & 0 & $1020 \pm 30$ \\
\hline Atlantic & ship & $0^{\circ} \mathrm{S}-5^{\circ} \mathrm{S}$ & April & $\mathbf{0}$ & $450 \pm 20$ \\
\hline Atlantic & ship & $5^{\circ} \mathrm{S}-10^{\circ} \mathrm{S}$ & April & $\mathbf{0}$ & $380 \pm 15$ \\
\hline Atlantic & ship & $10^{\circ} \mathrm{S}-20^{\circ} \mathrm{S}$ & April & 0 & $300 \pm 23$ \\
\hline Atlantic & ship & $20^{\circ} \mathrm{S}-30^{\circ} \mathrm{S}$ & April & $\mathbf{0}$ & $190 \pm 7$ \\
\hline Atlantic & ship & $30^{\circ} \mathrm{S}-40^{\circ} \mathrm{S}$ & April & $\mathbf{0}$ & $240 \pm 20$ \\
\hline Atlantic & ship & $30^{\circ} \mathrm{N}-45^{\circ} \mathrm{N}$ & April & $\mathbf{0}$ & $2100 \pm 110$ \\
\hline Atlantic & ship & $10^{\circ} \mathrm{N}-30^{\circ} \mathrm{N}$ & April & 0 & $1500 \pm 100$ \\
\hline Atlantic & ship & $0^{\circ} \mathrm{N}-10^{\circ} \mathrm{N}$ & April & $\mathbf{0}$ & $1000 \pm 130$ \\
\hline Atlantic & ship & $0^{\circ} \mathrm{N}-10^{\circ} \mathrm{S}$ & April & $\mathbf{0}$ & $500 \pm 130$ \\
\hline Atlantic & ship & $10^{\circ} \mathrm{S}-30^{\circ} \mathrm{S}$ & April & 0 & $330 \pm 35$ \\
\hline Atlantic & ship & $30^{\circ} \mathrm{S}-55^{\circ} \mathrm{S}$ & April & 0 & $270 \pm 27$ \\
\hline Atlantic & ship & $55^{\circ} \mathrm{S}-75^{\circ} \mathrm{S}$ & April & 0 & $330 \pm 340$ \\
\hline Western Europe & airplane & $55^{\circ} \mathrm{N}-65^{\circ} \mathrm{N}$ & April & $2-11$ & $1600 \pm 450$ \\
\hline Western Europe & airplane & $45^{\circ} \mathrm{N}-55^{\circ} \mathrm{N}$ & April & $2-11$ & $1140 \pm 570$ \\
\hline East Coast North America & airplane & $55^{\circ} \mathrm{N}-65^{\circ} \mathrm{N}$ & April & $2-11$ & $1800 \pm 200$ \\
\hline East Coast North America & airplane & $35^{\circ} \mathrm{N}-55^{\circ} \mathrm{N}$ & April & 2-11 & $1700 \pm 140$ \\
\hline East Coast North America & airplane & $15^{\circ} \mathrm{N}-35^{\circ} \mathrm{N}$ & April & $2-11$ & $1100 \pm 170$ \\
\hline Central America & airplane & $5^{\circ} \mathrm{N}-15^{\circ} \mathrm{N}$ & April & 2-11 & $680 \pm 80$ \\
\hline Central America & airplane & $5^{\circ} \mathrm{N}-10^{\circ} \mathrm{S}$ & April & $2-11$ & $510 \pm 20$ \\
\hline West Coast South America & airplane & $10^{\circ} \mathrm{S}-35^{\circ} \mathrm{S}$ & April & $2-11$ & $300 \pm 40$ \\
\hline West Coast South America & airplane & $35^{\circ} \mathrm{S}-55^{\circ} \mathrm{S}$ & April & 2-11 & $460 \pm 180$ \\
\hline East Coast South America & airplane & $10^{\circ} \mathrm{S}-35^{\circ} \mathrm{S}$ & May & $2-11$ & $300 \pm 40$ \\
\hline Atlantic & airplane & $5^{\circ} \mathrm{N}-10^{\circ} \mathrm{S}$ & May & 2-11 & $500 \pm 60$ \\
\hline West Coast Africa & airplane & $10^{\circ} \mathrm{N}-30^{\circ} \mathrm{N}$ & May & $2-11$ & $890 \pm 70$ \\
\hline Pacific & ship & $24^{\circ} \mathrm{N}$ & May & $\mathbf{0}$ & $1250 \pm 110$ \\
\hline Atlantic & ship & $60^{\circ} \mathrm{N}-80^{\circ} \mathrm{N}$ & May & $\mathbf{0}$ & $1380 \pm 100$ \\
\hline France & airplane & $45^{\circ} \mathrm{N}$ & June & $0.6-6.5$ & $1700 \pm 170$ \\
\hline Western Europe & airplane & $55^{\circ} \mathrm{N}-65^{\circ} \mathrm{N}$ & June & $1-11$ & $2200 \pm 150$ \\
\hline Western Europe & airplane & $45^{\circ} \mathrm{N}-55^{\circ} \mathrm{N}$ & June & $1-11$ & $1360 \pm 140$ \\
\hline East Coast North America & airplane & $55^{\circ} \mathrm{N}-65^{\circ} \mathrm{N}$ & June & $1-11$ & $1700 \pm 130$ \\
\hline East Coast North America & airplane & $35^{\circ} \mathrm{N}-55^{\circ} \mathrm{N}$ & June & $1-11$ & $1900 \pm 200$ \\
\hline East Coast North America & airplane & $15^{\circ} \mathrm{N}-35^{\circ} \mathrm{N}$ & June & $1-11$ & $1900 \pm 300$ \\
\hline Central America & airplane & $5^{\circ} \mathrm{N}-15^{\circ} \mathrm{N}$ & June & $1-11$ & $1100 \pm 160$ \\
\hline Central America & airplane & $5^{\circ} \mathrm{N}-10^{\circ} \mathrm{S}$ & June & $1-11$ & $1170 \pm 240$ \\
\hline West Coast South America & airplane & $10^{\circ} \mathrm{S}-35^{\circ} \mathrm{S}$ & June & $1-11$ & $510 \pm 40$ \\
\hline West Coast South America & airplane & $35^{\circ} \mathrm{S}-55^{\circ} \mathrm{S}$ & June & $1-11$ & $310 \pm 30$ \\
\hline East Coast South America & airplane & $10^{\circ} \mathrm{S}-35^{\circ} \mathrm{S}$ & June & $1-11$ & $440 \pm 60$ \\
\hline Atlantic & airplane & $7^{\circ} \mathrm{N}-10^{\circ} \mathrm{S}$ & June & $9-11$ & $560 \pm 50$ \\
\hline West Coast Africa & airplane & $10^{\circ} \mathrm{N}-30^{\circ} \mathrm{N}$ & June & $1-11$ & $870 \pm 50$ \\
\hline West Coast Africa/Europe & airplane & $30^{\circ} \mathrm{N}-45^{\circ} \mathrm{N}$ & June & $1-11$ & $1200 \pm 250$ \\
\hline
\end{tabular}


Table 1. Continued

\begin{tabular}{|c|c|c|c|c|c|}
\hline Region & Platform & Latitude & Month & $\begin{array}{c}\text { Altitude, } \\
\text { km* }^{*}\end{array}$ & $\underset{\text { ppt }^{\dagger}}{\text { Mixing Ratio }}$ \\
\hline Western Europe & airplane & $55^{\circ} \mathrm{N}-65^{\circ} \mathrm{N}$ & June & $1-11$ & $3300 \pm 300$ \\
\hline French Atlantic Coast & airplane & $50^{\circ} \mathrm{N}$ & July & $0.5-11$ & $1150 \pm 50$ \\
\hline France & airplane & $50^{\circ} \mathrm{N}$ & July & $0.5-11$ & $1300 \pm 60$ \\
\hline Ireland & airplane & $52^{\circ} \mathrm{N}$ & July & $1.2-6.5$ & $1400 \pm 300$ \\
\hline Atlantic & ship & $5^{\circ} \mathrm{S}-3^{\circ} \mathrm{N}$ & August & $\mathbf{0}$ & $900 \pm 50$ \\
\hline Atlantic & ship & $40^{\circ} \mathrm{N}-50^{\circ} \mathrm{N}$ & August & $\mathbf{0}$ & $890 \pm 30$ \\
\hline Atlantic & ship & $30^{\circ} \mathrm{N}-40^{\circ} \mathrm{N}$ & August & $\mathbf{0}$ & $404 \pm 4$ \\
\hline Atlantic & ship & $20^{\circ} \mathrm{N}-30^{\circ} \mathrm{N}$ & August & $\mathbf{0}$ & $480 \pm 70$ \\
\hline Atlantic & ship & $10^{\circ} \mathrm{N}-20^{\circ} \mathrm{N}$ & August & $\mathbf{0}$ & $340 \pm 20$ \\
\hline Atlantic & ship & $5^{\circ} \mathrm{N}-10^{\circ} \mathrm{N}$ & August & $\mathbf{0}$ & $400 \pm 50$ \\
\hline Atlantic & ship & $0^{\circ} \mathrm{N}-5^{\circ} \mathrm{N}$ & August & $\mathbf{0}$ & $460 \pm 30$ \\
\hline Atlantic & ship & $0^{\circ} \mathrm{S}-5^{\circ} \mathrm{S}$ & August & 0 & $460 \pm 10$ \\
\hline Atlantic & ship & $5^{\circ} \mathrm{S}-10^{\circ} \mathrm{S}$ & August & $\mathbf{0}$ & $390 \pm 22$ \\
\hline Atlantic & ship & $10^{\circ} \mathrm{S}-20^{\circ} \mathrm{S}$ & August & $\mathbf{0}$ & $390 \pm 4$ \\
\hline Atlantic & ship & $20^{\circ} S-30^{\circ} S$ & August & 0 & $410 \pm 10$ \\
\hline Norway & airplane & $70^{\circ} \mathrm{N}$ & September & $0.6-6.5$ & $1350 \pm 400$ \\
\hline Atlantic & ship & $40^{\circ} \mathrm{N}-50^{\circ} \mathrm{N}$ & September & 0 & $670 \pm 50$ \\
\hline Atlantic & ship & $30^{\circ} \mathrm{N}-40^{\circ} \mathrm{N}$ & September & $\mathbf{0}$ & $600 \pm 40$ \\
\hline Atlantic & ship & $20^{\circ} \mathrm{N}-30^{\circ} \mathrm{N}$ & September & $\mathbf{0}$ & $490 \pm 50$ \\
\hline Atlantic & ship & $10^{\circ} \mathrm{N}-20^{\circ} \mathrm{N}$ & September & $\mathbf{0}$ & $720 \pm 40$ \\
\hline Atlantic & ship & $5^{\circ} \mathrm{N}-10^{\circ} \mathrm{N}$ & September & $\mathbf{0}$ & $560 \pm 120$ \\
\hline Atlantic & ship & $0^{\circ} \mathrm{N}-5^{\circ} \mathrm{N}$ & September & $\mathbf{0}$ & $510 \pm 60$ \\
\hline Atlantic & ship & $0^{\circ} \mathrm{S}-5^{\circ} \mathrm{S}$ & September & 0 & $590 \pm 20$ \\
\hline Atlantic & ship & $5^{\circ} \mathrm{S}-10^{\circ} \mathrm{S}$ & September & $\mathbf{0}$ & $560 \pm 32$ \\
\hline Atlantic & ship & $10^{\circ} \mathrm{S}-20^{\circ} \mathrm{S}$ & September & $\mathbf{0}$ & $550 \pm 14$ \\
\hline Atlantic & ship & $20^{\circ} \mathrm{S}-30^{\circ} \mathrm{S}$ & September & $\mathbf{0}$ & $380 \pm 27$ \\
\hline Atlantic & ship & $30^{\circ} \mathrm{S}-40^{\circ} \mathrm{S}$ & September & 0 & $240 \pm 20$ \\
\hline Germany & airplane & $50^{\circ} \mathrm{N}$ & October & $1-4$ & $2400 \pm 230$ \\
\hline Germany & airplane & $48^{\circ} \mathrm{N}$ & November & $2-10$ & $1300 \pm 200$ \\
\hline Ireland & airplane & $52^{\circ} \mathrm{N}$ & November & $1-5$ & $3800 \pm 550$ \\
\hline Western Europe & airplane & $45^{\circ} \mathrm{N}-47^{\circ} \mathrm{N}$ & December & $1-11$ & $710 \pm 330$ \\
\hline Mediterranean Sea & airplane & $41^{\circ} \mathrm{N}$ & December & $0.5-5$ & $5200 \pm 700$ \\
\hline Western Europe & airplane & $40^{\circ} \mathrm{N}-48^{\circ} \mathrm{N}$ & December & $1-11$ & $800 \pm 120$ \\
\hline West Coast Africa & airplane & $15^{\circ} \mathrm{N}-30^{\circ} \mathrm{N}$ & December & $1-11$ & $1260 \pm 130$ \\
\hline West Coast Africa & airplane & $4^{\circ} \mathrm{N}-5^{\circ} \mathrm{S}$ & December & $1-11$ & $890 \pm 60$ \\
\hline West Coast Africa & airplane & $4^{\circ} \mathrm{S}-5^{\circ} \mathrm{S}$ & December & $1-11$ & $1000 \pm 180$ \\
\hline West Africa & airplane & $2^{\circ} \mathrm{S}-5^{\circ} \mathrm{S}$ & December & $1-11$ & $1140 \pm 120$ \\
\hline West Africa & airplane & $3^{\circ} \mathrm{S}-3^{\circ} \mathrm{N}$ & December & $1-11$ & $1160 \pm 110$ \\
\hline West Coast Africa & airplane & $2^{\circ} \mathrm{N}-5^{\circ} \mathrm{N}$ & December & $1-11$ & $1450 \pm 270$ \\
\hline West Africa & airplane & $4^{\circ} \mathrm{N}-10^{\circ} \mathrm{N}$ & December & $1-11$ & $1960 \pm 290$ \\
\hline West Africa & airplane & $5^{\circ} \mathrm{N}-15^{\circ} \mathrm{N}$ & December & $1-11$ & $1160 \pm 120$ \\
\hline West Coast Africa & airplane & $15^{\circ} \mathrm{N}-30^{\circ} \mathrm{N}$ & December & $1-11$ & $960 \pm 100$ \\
\hline French Atlantic Coast & airplane & $45^{\circ} \mathrm{N}$ & December & $1-11$ & $1460 \pm 70$ \\
\hline French Pyrenees & airplane & $43.5^{\circ} \mathrm{N}$ & December & $2-11$ & $1070 \pm 60$ \\
\hline Northern Spain & airplane & $42.5^{\circ} \mathrm{N}$ & December & $1-11$ & $1500 \pm 110$ \\
\hline Canadian Arctic & station & $84^{\circ} \mathrm{N}$ & time series & 0 & sine fit $^{\ddagger}$ \\
\hline Antarctica & station & $70^{\circ} \mathrm{S}$ & time series & 0 & sine $\mathrm{fit}^{8}$ \\
\hline
\end{tabular}

*An altitude of 0 indicates measurements near ground level $(<50 \mathrm{~m})$.

${ }^{\dagger}$ The given error mainly represents the atmospheric variability of the ethane mixing ratios; the analytical error generally contributes only slightly to the total uncertainty.

${ }^{q} \mathrm{~A}$ sine fit of the ethane mixing ratios as function of season gave an average of $2033 \pm 60 \mathrm{ppt}$ and an amplitude of $1220 \pm 80 \mathrm{ppt}$ with highest values in February.

${ }^{8}$ A sine fit of the ethane mixing ratios as function of season gave an average of $360 \pm 25$ ppt and an amplitude of $90 \pm 40$ ppt with highest values in August.

file is the result of a substantial amount of averaging and thus represents an average situation. Therefore the differences between the mean profile and the measurements by Donahue and Prinn [1993] suggest a somewhat unusual situation. Indeed, during the Soviet-American Gas and Aerosol Experiment (SAGA) 3 cruise the ITCZ was only poorly defined for four of the six equator crossings [Johnson et al., 1993] and thus higher values measured during SAGA 3 between the equator and $5^{\circ} \mathrm{S}$ probably reflect the impact of air masses from the northern hemisphere.

For the southern hemisphere, there are no recently published measurement series which would allow a detailed comparison with our average latitude-season profile. Therefore a considerable degree of uncertainty remains for the southern hemispheric part of the ethane distribution, until more detailed data become available.

\section{Tropospheric Distribution}

The global annual mean ethane mixing ratio (weighted for the air masses in the individual latitude bands) is $860 \mathrm{ppt}$; the northern and southern hemispheric annual mean is 1330 and 384 ppt, respectively. However, there are substantial gradients within the hemispheres, especially in the northern hemisphere. The annually averaged latitudinal variation is 


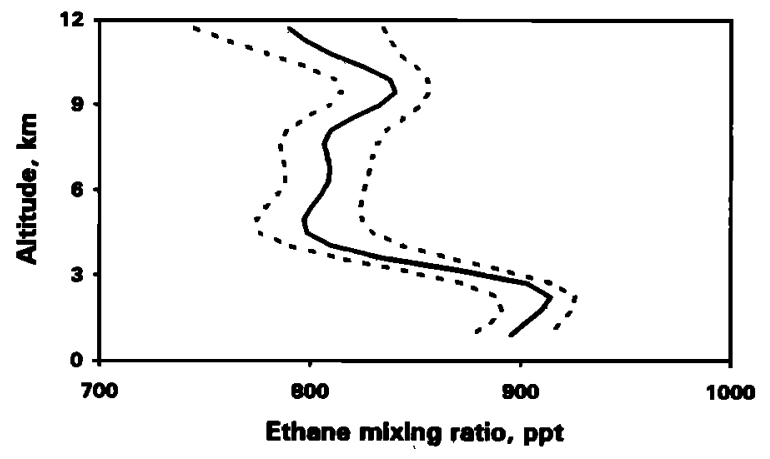

Figure 2. Mean vertical profile of the ethane mixing ratios, derived from the measurements made during STRATOZ III. Before averaging, the individual profiles were normalized to the global mean ethane mixing ratio of $860 \mathrm{ppt}$. Solid line, mean; dashed lines, mean \pm error of mean.

shown in Figure 7. Here the highest ethane mixing ratios of about $2500 \mathrm{ppt}$ are observed around $65^{\circ}-70^{\circ} \mathrm{N}$, and there is a slight decrease toward higher latitudes. Between $65^{\circ} \mathrm{N}$ and the equator the ethane mixing ratio decreases monotonically but not strictly linearly to about $600 \mathrm{ppt}$. The steepest gradients are found from $65^{\circ}$ to $50^{\circ} \mathrm{N}$ and from $25^{\circ}$ to $5^{\circ} \mathrm{N}$. Between the equator and $15^{\circ} \mathrm{S}$ there is a slight decrease from 550 to $350 \mathrm{ppt}$; otherwise there seem to be no significant latitudinal gradients in the southern hemisphere.

Also shown in Figure 7 are the latitudinal profiles for the months with the highest and lowest ethane mixing ratios in the northern hemisphere, February and August. For February the shape of the latitudinal ethane distribution in the northern hemisphere is very similar to the annual mean profile, but the mixing ratios are around $60 \%$ higher. In contrast to this the August profile shows only a small gradient between $15^{\circ} \mathrm{N}$ and $90^{\circ} \mathrm{N}$; the ethane mixing ratios in this latitude range remain fairly constant, around $700-800$ ppt. In the southern hemisphere the situation is reversed; the lowest ethane mixing ratios occur in February and the highest in August. Not only the phase of the annual cycle is shifted but also the relative magnitude of the seasonal variation in the southern hemisphere is lower than in the northern hemisphere. With a factor of 1.6 the seasonal variability in the southern hemisphere is clearly visible but relatively small compared to a factor exceeding 4 at high northern latitudes. The seasonal variability around the equator is only small, a result of the phase shift between the seasonal cycles in the two hemispheres.

The different phases and amplitudes of the seasonal cycles can be clearly seen from Figure 8 which shows the average northern and southern hemispheric as well as the global mean ethane mixing ratios as a function of season. The northern hemispheric average varies between $1900 \mathrm{ppt}$ in February and $800 \mathrm{ppt}$ in August. The phase of the southern hemispheric average seasonality is shifted by 6 months with a maximum around $450 \mathrm{ppt}$ in August and a minimum of $\mathbf{3 3 0}$ ppt in February. The global seasonal cycle is dominated by the changes in the northern hemisphere and thus the phase is the same as for the northern hemisphere. However, the amplitude is attenuated. On global average the change in the ethane mixing ratio between maximum and minimum is only about $60 \%$, from 1050 ppt in February to 650 ppt in August.

One of the consequences of the phase shift of the seasonal

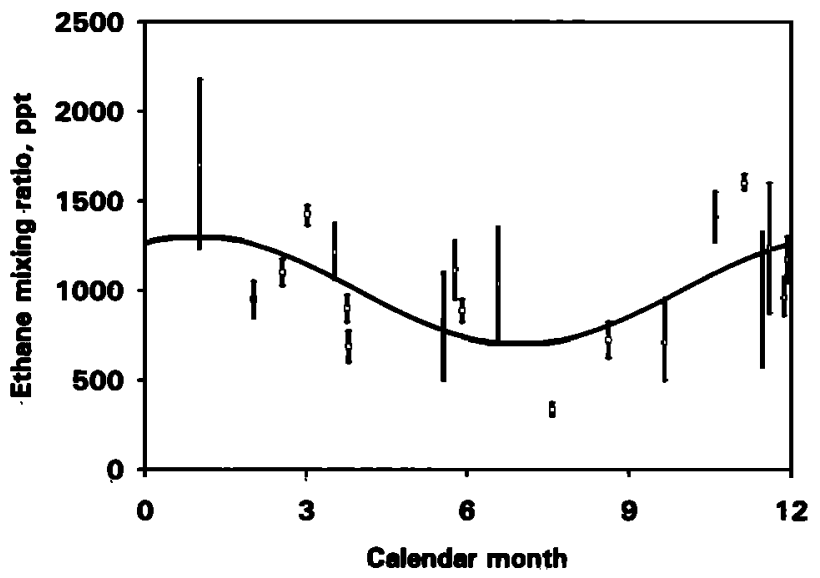

Figure 3. Example for the seasonal variation of the ethane mixing ratio at $15^{\circ} \mathrm{N}$ (latitude range $10^{\circ} \mathrm{N}-20^{\circ} \mathrm{N}$ ). The solid line shows the sinusoidal fit to the data. Open squares are measurements made in the laboratory at Jülich; solid squares are data taken from literature (details see text).

cycles between the two hemispheres is a strong seasonality of the interhemispheric gradient. The largest interhemispheric difference in the ethane mixing ratios of $1550 \mathrm{ppt}$ is observed in February, the lowest with 330 ppt in August. The annual mean interhemispheric gradient is about 950 ppt. The corresponding interhemispheric ratios range from nearly 6 to less than 2 with an average around 3.5.

\section{Tropospheric Removal}

The only known relevant removal mechanism for tropospheric ethane is the reaction with $\mathrm{OH}$ radicals. Therefore the tropospheric loss of ethane can be calculated from the ethane concentration, the $\mathrm{OH}$-radical concentration, and the rate constant for the reaction of ethane with $\mathrm{OH}$ radicals. We used the shape of the latitudinal, altitudinal, and seasonal OH-radical distribution published by Taylor et al. [1991] which was adopted from Brasseur et al. [1990] and scaled it to a global average OH-radical concentration of $6.4 \times 10^{5}$ molecules $\mathrm{cm}^{-3}$ to match the mean OH-radical concentration derived from the global budget of 14-CO [Volz et al., 1981]. The rate constant and its temperature dependence was taken from Atkinson et al. [1992] and the vertical and

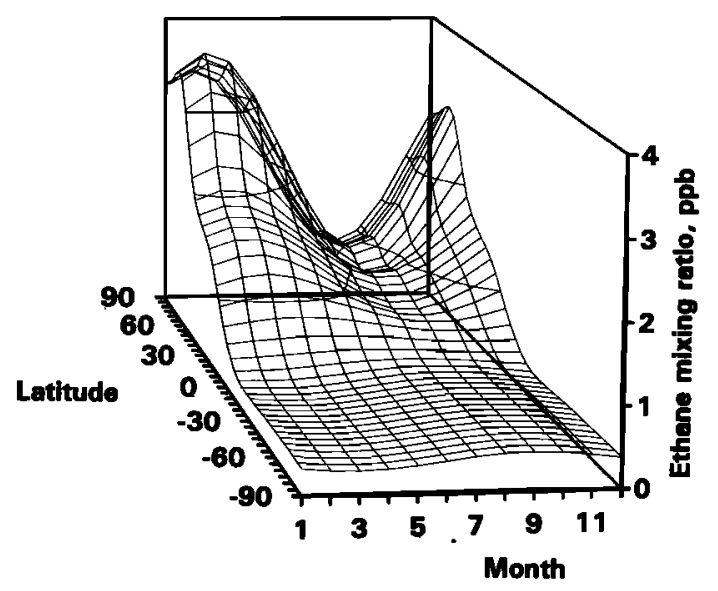

Figure 4. Latitudinal and seasonal variation of the longitudinally and altitudinally averaged ethane mixing ratio. 
latitudinal temperature profiles were extracted from the GISS three-dimensional model [Hansen et al., 1983]. The ethane concentration was derived from the latitude-season dependence (Figure 4) and the shape of the average vertical profile shown in Figure 2. The removal of ethane was calculated for each month in intervals of $10^{\circ}$ latitude and 1 $\mathrm{km}$ altitude. The loss of tropospheric ethane by transport into the stratosphere can be estimated from the average ethane concentrations in the troposphere and the troposphere-stratosphere exchange rate of about 0.8 year $^{-1}$ [cf. Warneck, 1988].

From this a tropospheric removal of ethane by reaction with $\mathrm{OH}$ radicals of $14.7 \mathrm{Tg} / \mathrm{yr}$ is calculated. Compared to this, the loss of $0.8 \mathrm{Tg} / \mathrm{yr}$ into the stratosphere is of minor importance for the global ethane budget. The total global turnover of ethane in the atmosphere thus amounts to $\mathbf{1 5 . 5}$ $\mathrm{Tg} / \mathrm{yr}$. As a result of uncertainties in the global ethane distribution (estimated on average to less than $30 \%$ ) and the error of the reaction rate constant for $\mathrm{OH}+\mathrm{C}_{2} \mathrm{H}_{6}$ and its temperature dependence (estimated to less than 25\% [cf. Atkinson et al., 1992]), this number has an error of about 6 $\mathrm{Tg} / \mathrm{yr}$. This does not include uncertainties from errors in the global OH-radical distributions or the possible existence of other removal mechanisms for ethane. The accuracy of the $\mathrm{OH}$-radical concentration distribution is very difficult to estimate and thus a source of considerable errors. However,
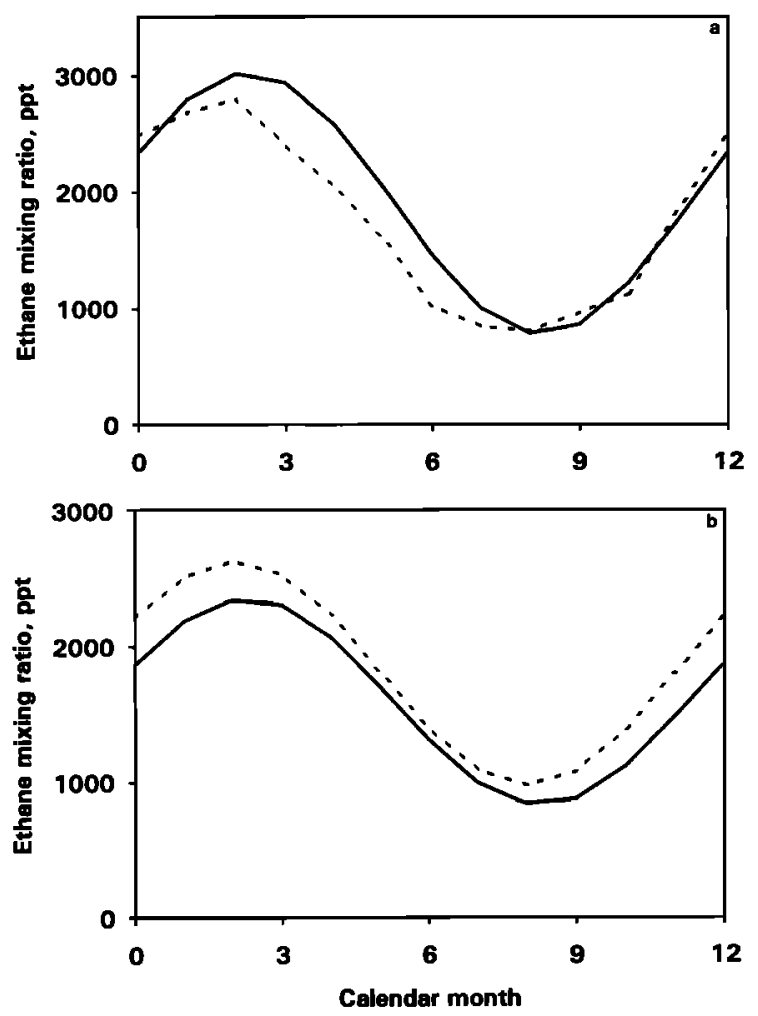

Figure 5. Comparison of seasonal cycles at different locations with the longitudinally averaged seasonality. (a) Rörvik, Sweden $\left(57^{\circ} 23^{\prime} \mathrm{N}, 11^{\circ} 55^{\prime} \mathrm{E}\right)$; solid line, longitudinal average for $57^{\circ} 30^{\prime} \mathrm{N}$ from this work; dashed line, measurements at Rörvik, data from Lindskog and Moldanova [1995]. (b) Fraserdale, Canada $\left(50^{\circ} \mathrm{N}, 82^{\circ} \mathrm{W}\right)$; solid line, longitudinal average for $50^{\circ} \mathrm{N}$ from this work; dashed line, measurements at Fraserdale, data from Jobson et al. [1994].
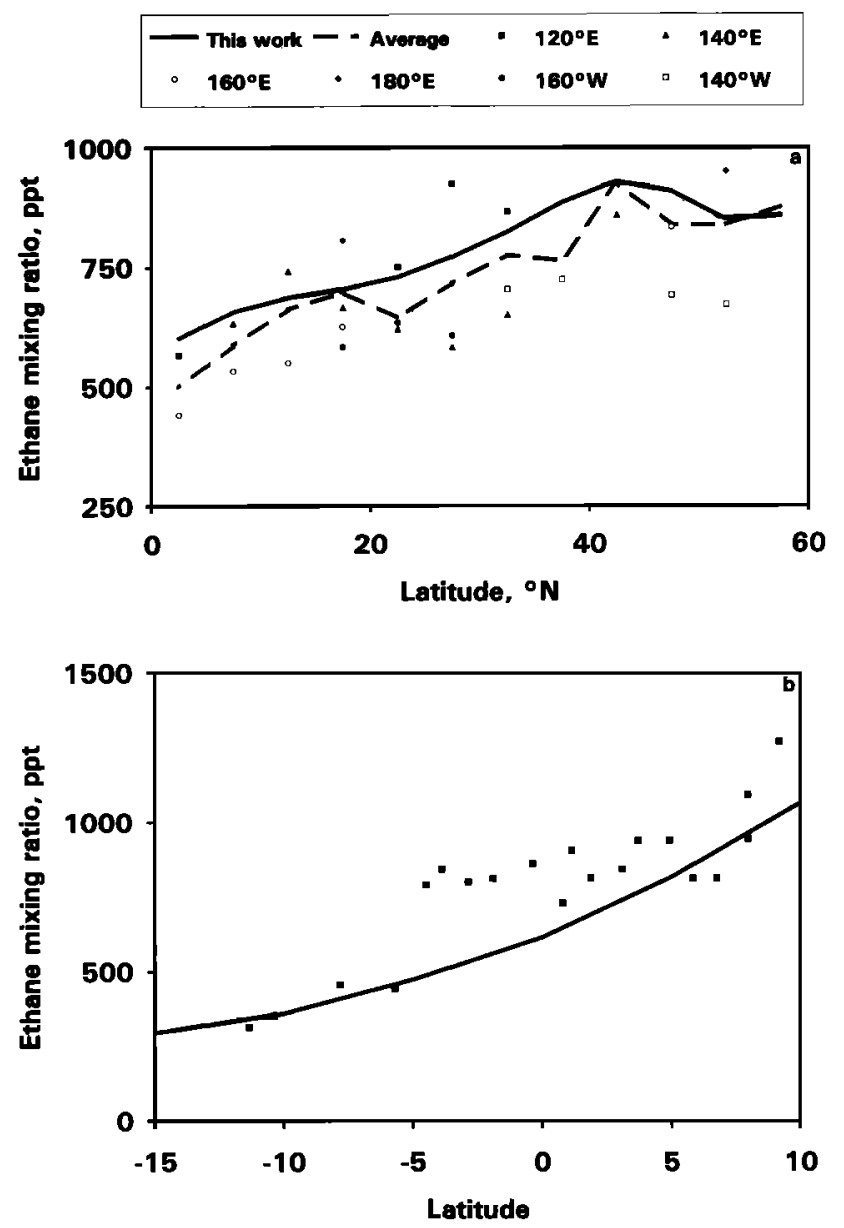

Figure 6. Comparison of latitudinal gradients at different longitudes with the longitudinal average. (a) Western Pacific (equator to $60^{\circ} \mathrm{N}, 115^{\circ} \mathrm{E}-122^{\circ} \mathrm{W}$ ); solid line, longitudinal average for September; dashed line, average of data from PEM-WEST A [Blake et al., 1995]. The different symbols indicate the mixing ratios at different longitudes, averaged over the three altitude levels for which the ethane mixing ratios are presented by Blake et al. [1995]. (b) Central Pacific $\left(15^{\circ} \mathrm{S}-10^{\circ} \mathrm{N}, 145-165^{\circ} \mathrm{W}\right)$; solid line, longitudinal average for March; squares, measurements by Donahue and Prinn [1994].

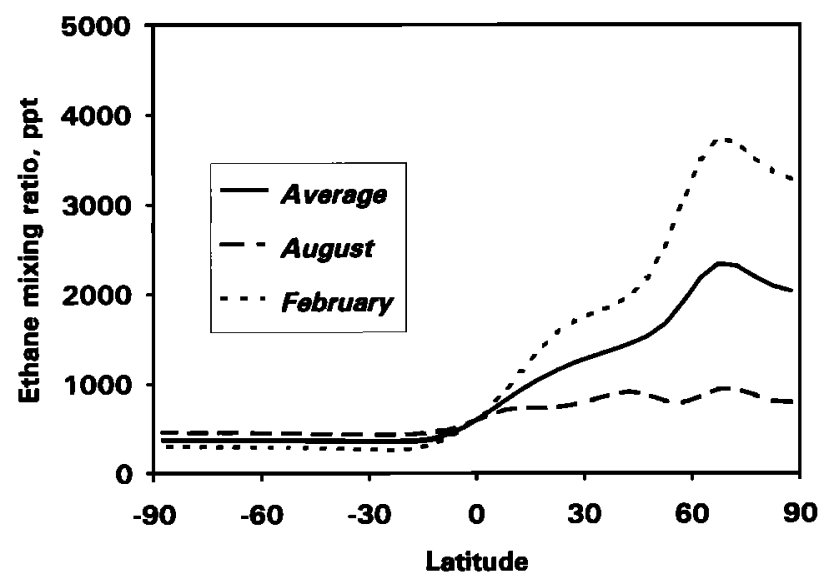

Figure 7. Latitudinal variation of the ethane mixing ratio. 


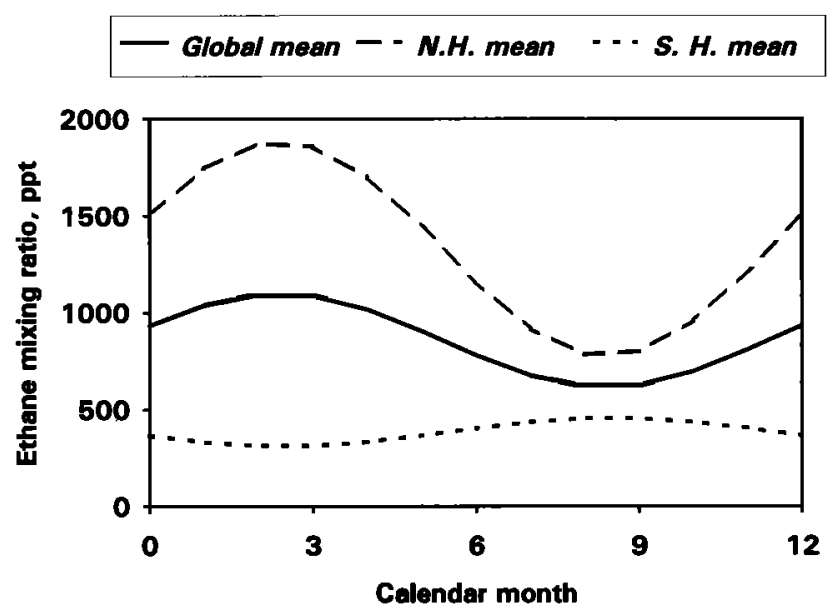

Figure 8. Seasonal variation of the global, northern hemispheric and southern hemispheric mixing ratios of ethane.

budget estimates of trace gases such as 14-CO [Volz et al., 1981] and methyl chloroform [Taylor et al., 1991; Prinn et al., 1983, 1987] indicate that the average tropospheric $\mathrm{OH}$ radical concentration is reasonably well known within an uncertainty of about 20\% [Hough, 1991]. The total uncertainty of the global ethane removal is therefore in the range of $45 \%$ corresponding to $7 \mathrm{Tg} / \mathrm{yr}$.

Because of the interhemispheric asymmetry of the ethane concentrations the turnover in the northern hemisphere is about $11.8 \mathrm{Tg} / \mathrm{yr}$, approximately 3 times higher than the turnover of $3.7 \mathrm{Tg} / \mathrm{yr}$ in the southern hemisphere. On the basis of an interhemispheric exchange time of about 1 year for the troposphere [Warneck, 1988] and the interhemispheric ethane gradient calculated from the mean hemispheric ethane mixing ratios, a flux of about $2 \mathrm{Tg} / \mathrm{yr}$ from the northern to the southern hemisphere can be calculated. Thus the source strength required to balance the southern hemispheric ethane budget is in the range of $2 \mathrm{Tg} / \mathrm{yr}$. By far the largest sources, roughly $13-14 \mathrm{Tg} / \mathrm{yr}$, are required in the northern hemisphere.

The seasonality of the global budget of ethane can be described by

$$
d m / d t+P-D=0
$$

where $d m / d t$ is the seasonal change of the tropospheric ethane content; $P$ is the source strength for all tropospheric ethane sources; and $D$ is the removal rate. The removal rate can be calculated as a function of time from the $\mathrm{OH}$-radical concentrations and the tropospheric ethane distribution (see above) and $d m / d t$ from the change of the ethane concentrations as a function of season. This allows to deduce the source strength $(P)$ required to balance the budget as a function of season.

In Figure 9 the seasonal variation of removal, change of the atmospheric ethane content, and the required source strength is shown for the total troposphere (Figure 9a) and for the two hemispheres (Figures $9 \mathrm{~b}$ and 9c). For the two hemispheres, also the interhemispheric exchange has to be considered. As a simplified approximation, it is assumed that the exchange rate is proportional to the difference in the monthly mean ethane concentrations between the two hemispheres. The monthly exchange coefficient is taken to be
$1 / 12$ of the annual exchange time of one year. This neglects a possible seasonality of the interhemispheric exchange coefficient. The global atmospheric removal (see Figure 9a) peaks in April, but the required source to balance atmospheric losses and the change of the atmospheric ethane contents has its maximum in December and the lowest value
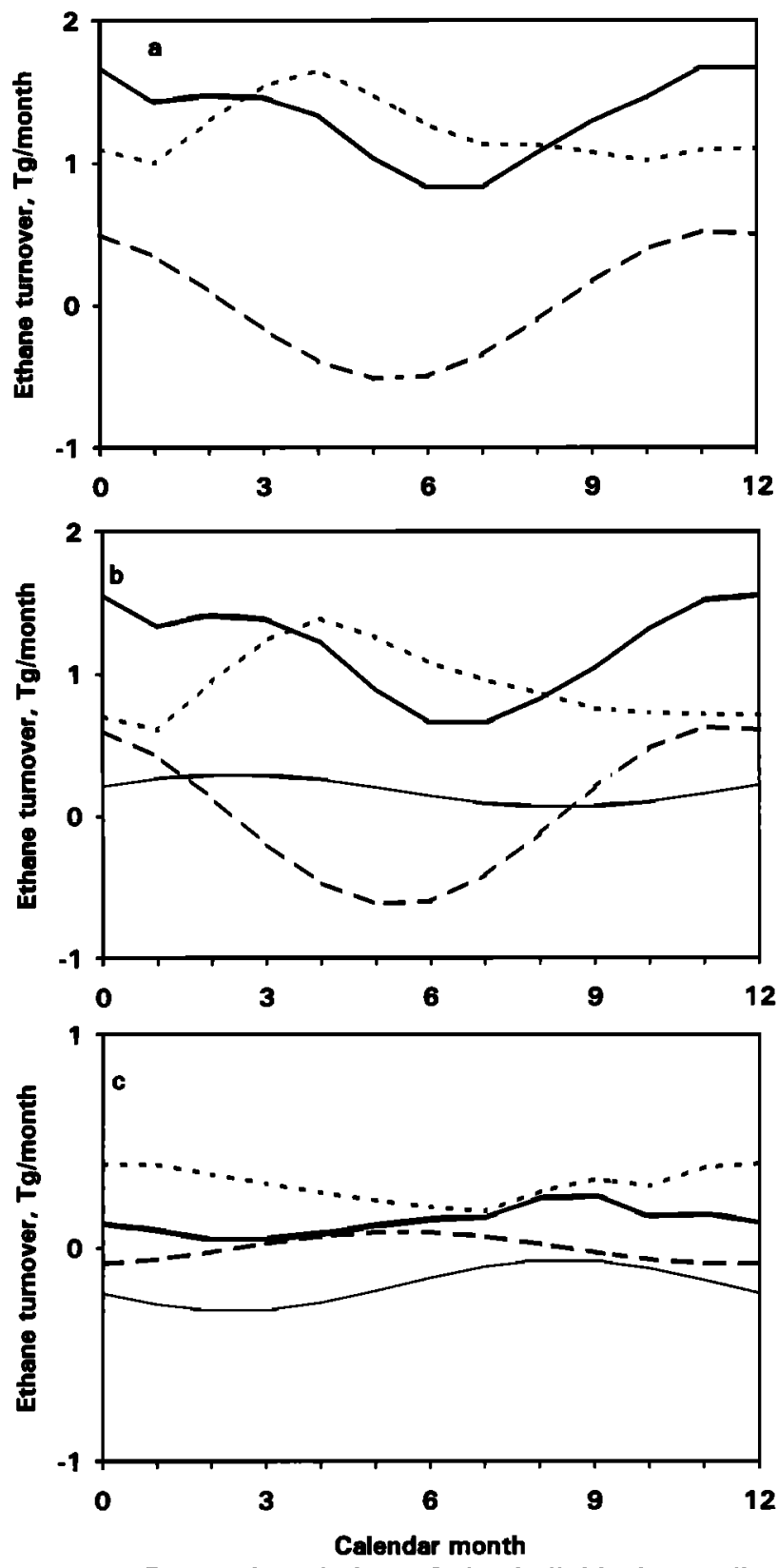

Figure 9. Seasonal variation of the individual contributions to the monthly tropospheric budget of ethane. The "required source" is calculated from the sum of all other contributions. (a) Total troposphere: short-dashed line, removal by $\mathrm{OH}$ radicals; long-dashed line, change of the atmospheric ethane content; solid line, required source. (b) Northern hemisphere: short-dashed line, removal by $\mathrm{OH}$ radicals; long-dashed line, change of the hemispheric ethane content; thin line, interhemispheric exchange; thick line, required source. (c) Southern hemisphere: short-dashed line, removal by $\mathrm{OH}$ radicals; long-dashed line, change of the hemispheric ethane content; thin line, interhemispheric exchange; thick line, required source. 
in June/July. The indirectly derived seasonalities of the source strength are composed of two components and thus have a considerable uncertainty. However, the difference between a required source of $0.8 \mathrm{Tg} /$ month in June/July and $1.6 \mathrm{Tg} /$ month in December is rather striking and cannot be explained completely by uncertainties of the estimates and thus suggests a seasonality of the ethane emission rates. From a comparison of the global (Figure 9a) and hemispheric budgets (Figure $9 \mathrm{~b}$ and $9 \mathrm{c}$ ), it is evident that both the shape and the magnitude of the seasonality of the indirectly derived global ethane source is dominated by the processes in the northern hemisphere. The required southern hemispheric source (Figure 9c) contributes in all seasons only about $10-20 \%$ to the global budget. There is some indication of a maximum in August/September, but the required source strength is always rather low, between 0.05 and $0.25 \mathrm{Tg}$ / month. However, this variation is still within the uncertainty of the estimate.

We can obtain a more detailed overview over the latitudinal source distribution from the latitudinal ethane distribution and the one-dimensional latitudinal eddy diffusion coefficients [cf. Czeplak and Junge, 1974]. The latitudinal ethane concentration profiles were smoothed twice by a third-order Chebyshev polynomial to reduce the random noise before the latitudinal net ethane flux was calculated from the second derivative of the concentration profile and the latitudinal eddy diffusion coefficient for each $5^{\circ}$ latitude interval:

$$
F=K_{y}\left(d^{2} c / d y^{2}\right)
$$

The results are shown in Figure 10. From the effect of transport and the removal by $\mathrm{OH}$ radicals, the required source strength to maintain the atmospheric balance can be calculated (see Figure 10). Because of the substantial amount of smoothing and the extremely simplified transport parameterization, we can only expect a rough, first-order estimate of the source distribution. As mentioned before, the ethane emissions in the southern hemisphere are rather small; the strongest southern Hemispheric sources seem to be located at tropical latitudes. The amount of ethane transported from the northern hemisphere into the southern hemisphere calculated from the latitudinal eddy diffusion coefficients is roughly $1.5 \mathrm{Tg} / \mathrm{yr}$, slightly lower than the 2 $\mathrm{Tg} / \mathrm{yr}$ calculated from an interhemispheric exchange time of about 1 year (see above). The small difference of $0.5 \mathrm{Tg} / \mathrm{yr}$ is well within the uncertainties of the individual estimates.

There are significant ethane sources at low northern latitudes, but a significant fraction of the total ethane emissions occurs at middle and high northern latitudes. About 8 $\mathrm{Tg} / \mathrm{yr}$ are emitted north of $25^{\circ} \mathrm{N}$ and nearly half of the total northern hemispheric sources are located north of $40^{\circ} \mathrm{N}$. North of $45^{\circ} \mathrm{N}$, the emissions exceed the atmospheric removal and thus this area acts as net source. About $2.5 \mathrm{Tg} / \mathrm{yr}$ are exported from this region to lower latitudes where the sources do not balance the atmospheric removal.

It is interesting to note that the ethane sources at high northern latitudes $\left(>65^{\circ} \mathrm{N}\right)$ are with roughly $2.5 \mathrm{Tg} / \mathrm{yr}$ comparable in magnitude to the total ethane emissions in the southern hemisphere. The large ethane emissions at high northern latitudes seem to support the speculation that the Arctic troposphere can act as a reservoir which accumulates organic trace gases in winter as a result of the slow exchange with lower latitudes [cf. Lightman et al., 1990]. These trace gases can be released in spring during the breakup of the

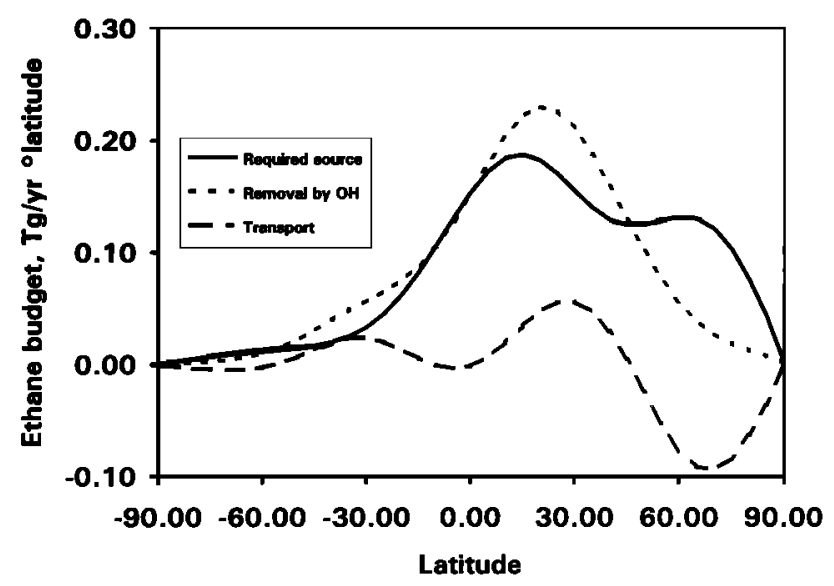

Figure 10. Latitudinal dependence of the removal by $\mathrm{OH}$ radicals, latitudinal transport, and required source strength of ethane. The values are given per degree latitude and year. A negative value of the transport contribution indicates a loss from the latitude belt.

Arctic circulation and then may contribute significantly to the turnover of organic trace gases at lower latitudes. The change in the ethane content of the troposphere at high northern latitudes $\left(>60^{\circ} \mathrm{N}\right)$ between February and July is 0.7 $\mathrm{Tg}$. This is about $20 \%$ of the annual emissions of about 3.5 $\mathrm{Tg} / \mathrm{yr}$ for the region north of $55^{\circ} \mathrm{N}$ and about $5 \%$ of the global annual ethane emissions. Thus the Arctic reservoir is of minor importance for ethane, although not negligible.

\section{Comparison With Emission Estimates}

Existing ethane emission estimates. There are some indirect estimates of the atmospheric ethane source strength based on budget considerations and atmospheric removal rates. On the basis of atmospheric measurements made by Rasmussen and Khalil [1982], Penkett [1982] calculated a global ethane source strength of $5 \mathrm{Tg} / \mathrm{yr}$. Isaksen et al. [1985] derived a global ethane source strength of $10 \mathrm{Tg} / \mathrm{yr}$ from the measurements made by Singh and Salas [1982] at Point Arena. Similar types of estimates were made by Blake and Rowland [1986] and Kanakidou et al. [1991]. Their estimates, which were based on more extensive sets of atmospheric ethane measurements, gave higher global emission rates of 13 and $16 \mathrm{Tg} / \mathrm{yr}$, respectively. There are also a few direct assessments of the ethane source strength. The first overview over global ethane sources was given by Ehhalt and Rudolph [1984]. They were able to identify a number of sources which emitted ethane into the atmosphere, namely, oceanic emissions, microbial production, vegetation, biomass burning, and natural gas losses. They also considered a few very minor sources such as engine exhaust and losses from chemical industry. These sources amounted to about $7.6 \mathrm{Tg} / \mathrm{yr}$ of ethane. In more recent estimates, Singh and Zimmerman [1990] and Hough [1991] obtained higher ethane emission rates of $10-15$ and $29 \mathrm{Tg} / \mathrm{yr}$, respectively.

Evidently, there are large uncertainties in the magnitude of the global ethane sources and the global ethane budget seems to be not yet really understood. During the past years, there has been a number of studies of the sources of light NMHC, including ethane, and for some of the sources it seems possible to obtain more reliable estimates. 
Nonbiogenic ethane emissions. The global ethane emissions from biomass burning can be calculated from the emission ratios of ethane relative to carbon dioxide or carbon monoxide and existing estimates of the global emission rates of carbon dioxide or carbon monoxide from biomass burning. There are a number of studies of the ethane/carbon dioxide emission ratio for biomass burning. They range from $0.04 \%$ (volume) to $0.18 \%$ with an average of $0.09 \% \pm 0.06 \%$ [cf. Rudolph et al., 1994, 1995]. On the basis of carbon dioxide emissions of $1600-4100 \mathrm{Tg} \mathrm{C} / \mathrm{yr}$ from biomass burning [Crutzen and Andreae, 1990] an ethane source strength in the range of 3-10 $\mathrm{Tg} / \mathrm{yr}$ can be derived with a best estimate of $6.4 \mathrm{Tg} / \mathrm{yr}$. The same type of calculation based on the ethane/carbon monoxide emission ratio gives very similar results, a range of $2.4-12 \mathrm{Tg} / \mathrm{yr}$ with 6.8 $\mathrm{Tg} / \mathrm{yr}$ as best estimate.

By far the largest fraction of the man-made-industrial ethane emissions seem to be due to natural gas losses [Mayrsohn and Crabtree, 1976; Nelson et al., 1983; Ehhalt and Rudolph, 1984]. There are no direct investigations of the ethane emissions from natural gas losses. Generally, the emissions are estimated from the contributions of natural gas losses to the global methane budget and the ethane/methane ratio in natural gas. Lelieveld and Crutzen [1993] estimate that methane losses from gas and oil drilling, gas venting, gas transmission, and distribution are $80 \pm 45 \mathrm{Tg} / \mathrm{yr}$. Another $35 \pm 10 \mathrm{Tg} / \mathrm{yr}$ of fossil methane is emitted due to coal mining. The ethane/methane ratio in natural gas is highly variable and strongly depends on the origin of the gas. The NMHC/ methane ratio is rather low in "dry" bacterial and late mature gases but may be as high as $20 \%$ in "wet" oil associated gases [cf. Whiticar, 1990]. Ehhalt and Rudolph [1984] used a methane/NMHC ratio of 5 which is the average for the United States and assumed that about one fifth (by weight) of these NMHC consists of ethane. This results in an overall ethane content of natural gas of about $4 \%$ (by weight). For the United Kingdom the ethane/methane ratio from natural gas losses seems somewhat larger, about $6.5 \%$ [Photochemical Oxidants Review Group (PORG), 1987]. Based on these numbers, a global ethane emission in the range of $2.6-11 \mathrm{Tg} / \mathrm{yr}$ with a best estimate of $6 \mathrm{Tg} / \mathrm{yr}$ can be calculated. As a consequence of the variability of the ethane content of natural gas, this estimate is rather uncertain and may be easily refined if more representative data about the NMHC content of natural gas become available. It should be mentioned that the natural gas loss in the former Soviet Union alone is estimated to be $25 \pm 10 \mathrm{Tg} / \mathrm{yr}$ [Craig et al., 1993]. No representative estimate of the NMHC content of this source is available.

Biological ethane sources. The emissions of light hydrocarbons from the oceans have been studied in more detail during the past years [Bonsang et al., 1988; Plass et al., 1990; Plass-Dülmer et al., 1992, 1993; Donahue and Prinn, 1993; Ratte et al., 1995]. Although there is a substantial variability in the emission rate estimates, it seems now to be established that the oceanic source of ethane contributes only marginally to the global ethane budget. In a recent estimate, based on their own measurements of ethane concentrations in the ocean and the atmosphere and a detailed literature review, Plass-Dülmer et al. [1995] concluded that the ethane emissions from the open oceans are around 0.2 $\mathrm{Tg} / \mathrm{yr}$, with an upper limit of $0.5 \mathrm{Tg} / \mathrm{yr}$. Although there may be some uncertainty in these values, it can be ruled out that the oceans contribute significantly to the global ethane budget.

Extremely uncertain is the magnitude of ethane emissions from terrestrial biogenic sources. These are emissions from soils, wetlands, and vegetation. There are very few studies of wetland emissions, but in general the NMHC content in biogenic swamp gas is very low [cf. Whiticar, 1990]. Tyler et al. [1987] measured methane and light NMHC in swamp gas from the Amazonian basin. The ethane/methane ratios were 6-7 $\times 10^{-6}$ (by volume). Slightly higher but still marginal ratios of up to $4 \times 10^{-5}$ were found by J. Rudolph (unpublished results, 1981), in gas from a lake in Germany. If we use the methane emissions from wetlands, including rice fields, from Lelieveld and Crutzen [1993] of $195 \mathrm{Tg} / \mathrm{yr}$ to extrapolate these very limited data to a global scale, we obtain an ethane emission from wetlands in the range of $0.001-0.02 \mathrm{Tg} / \mathrm{yr}$. This estimate is highly uncertain, but the very low value suggests that ethane emissions from wetlands are insignificant for the atmospheric ethane budget.

The production of ethane in soils has been reported by Van Clemput et al. [1981]. They found a significant correlation between ethane and methane production with an ethane/ methane ratio of $7 \times 10^{-4}$. This was used by Warneck [1988] to extrapolate these results to a total global microbial source for ethane of $0.4 \mathrm{Tg} / \mathrm{yr}$. In a more recent study of Van Clemput et al. [1991] it was confirmed that the ethane concentrations in incubated soils follow the same pattern as the methane production but at about a factor of 500 lower concentrations. However, there are also indications of higher ethane emissions from soils. Hahn et al. [1991] observed ethane emission rates in the range of 4-14 nmol/ $\mathrm{m}^{2} / \mathrm{s}$ from the soil of a wheat field. This is of comparable magnitude or even higher than the total NMHC emissions found for several types of grasses and crops in the United States [cf. Altshuller, 1983] and suggests that soil emissions of ethane may be important. However, the very limited data do not justify any large-scale extrapolation.

On the basis of investigations by Zimmerman [1979], summarized by Altshuller [1983], Warneck [1988] estimated that vegetation, especially grassland, emits about $20 \mathrm{Tg} / \mathrm{yr}$ of light alkanes, including ethane as a major component. Hahn et al. [1991] measured the diurnal cycles of the ethane emission and deposition for wheat. During one of the days they observed emissions of up to $12 \mathrm{nmol} / \mathrm{m}^{2} / \mathrm{s}$ in the afternoon. However, for the same site they observed an ethane deposition in the range of $3-16 \mathrm{nmol} / \mathrm{m}^{2} / \mathrm{s}$ on two other days. In another paper, Hahn et al. [1992] mention that NMHC emission or deposition from wheat strongly depends on temperature and that high temperatures change deposition to emission. However, no quantitative data on the temperature dependence of the emission or deposition of ethane are given. Mechanistic studies of the ethane emissions from vegetation indicate that ethane production increases with increasing membrane damage [Konze and Elstner, 1978; Bucher, 1984]. This points toward extreme difficulties to extrapolate results from individual studies to a larger scale. From our present knowledge it is not possible to derive a meaningful estimate of the effect of vegetation on the atmospheric ethane budget.

In total it seems that the most important sources of atmospheric ethane are biomass burning with $6.4 \mathrm{Tg} / \mathrm{yr}$ and natural gas losses with $6 \mathrm{Tg} / \mathrm{yr}$. Both estimates have substantial uncertainties. The few minor sources (e.g., emissions 


\section{$\square$ Required sources $\square$ Other sources $\square$ Natural gas loss $\$$ biomass buming}

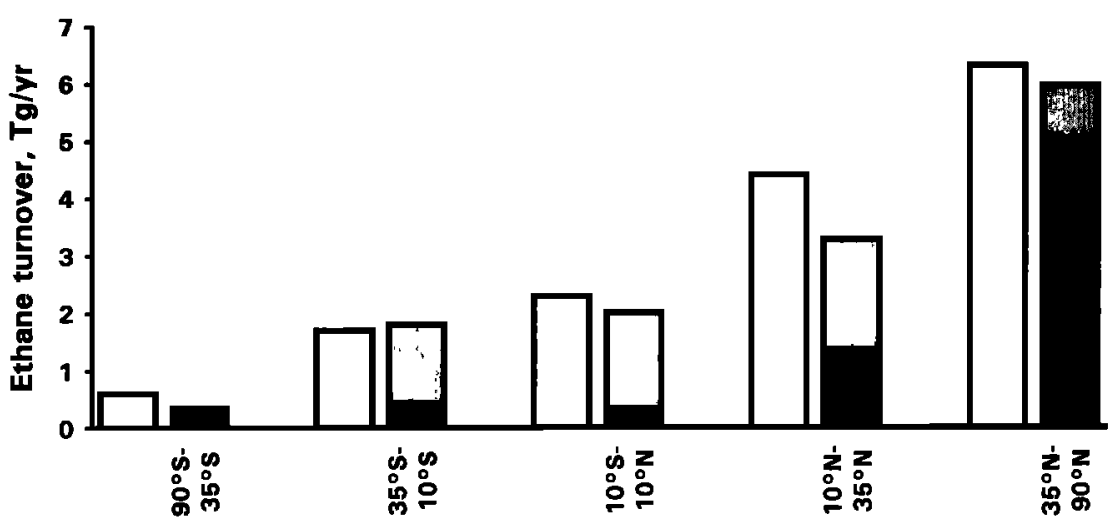

Figure 11. Budget of ethane for different latitude belts. "Other sources" represents a uniformly distributed $1 \mathrm{Tg} / \mathrm{yr}$ emission to account for a variety of minor sources (oceans, soil, wetlands, and various minor man-made emissions).

from oceans, soils and wetlands, and other man-made industrial sources besides natural gas losses) may add up to about $1 \mathrm{Tg} / \mathrm{yr}$. The resulting total of about $13 \mathrm{Tg} / \mathrm{yr}$ is, within the uncertainties of the estimates, sufficient to balance the atmospheric removal by $\mathrm{OH}$ radicals.

On the basis of latitude dependence of the different types of trace gas sources given by Hough [1991], we can estimate the latitudinal distribution of the ethane emissions (Figure 11). Biomass burning and natural gas losses as the main sources for atmospheric ethane are compatible with our estimated latitudinal distribution of the required atmospheric source. Also the seasonality of the indirectly derived ethane emissions in both hemispheres is, at least qualitatively, compatible with biomass burning as one major source for atmospheric ethane. This does not strictly rule out a contribution from vegetation, but from our budget the net contribution of any missing ethane source should be around only 2 $\mathrm{Tg} / \mathrm{yr}$ (Figure 11).

\section{Summary and Conclusions}

Our present knowledge of the ethane distribution in the troposphere allows to construct reasonably well defined longitudinally and altitudinally averaged seasonal and latitudinal profiles of the ethane mixing ratio. In both hemispheres the seasonal cycles show clear maxima in late winter and minima in late summer. The most pronounced seasonal changes are found at high northern latitudes, the lowest around the equator. In both hemispheres the seasonal cycles are strongly driven by the seasonality of the $\mathrm{OH}$-radical concentrations, but also, the seasonal variations of the sources seem to have a significant effect.

There is a strong interhemispheric gradient with an average ratio of 3.5 between the northern and the southern hemisphere. As a consequence, about $11.8 \mathrm{Tg} / \mathrm{yr}$ of ethane are turned over in the northern hemisphere, only 3.7 in the southern hemisphere. Losses of natural gas and biomass burning are the main sources which balance the total atmospheric ethane removal of $15.5 \mathrm{Tg} / \mathrm{yr}$. With 6 and $6.4 \mathrm{Tg} / \mathrm{yr}$, respectively, both sources contribute nearly equally. There are a few minor sources such as emissions from soils, wetlands, oceans, engine exhaust, and losses from industrial processes which may add up to about $1 \mathrm{Tg} / \mathrm{yr}$. These known sources seem to be able to balance most of the atmospheric removal and both the latitudinal and the seasonal variations of the sources are compatible with the observed atmospheric distributions. Nevertheless, there is still a large uncertainty about the role of vegetation as source or sink of atmospheric ethane.

In general, the atmospheric ethane budget seems to be reasonably well balanced and there is no indication for the existence of a major unknown source or sink. As there seem to be only two major sources of atmospheric ethane, ethane is probably a very useful tracer to study changes in the magnitude and distribution of these sources. Especially for the southern hemisphere, where biomass burning seems to be the dominant ethane source, atmospheric observations of ethane are a promising diagnostic tool to understand the seasonal and geographical distribution as well as secular trends of biomass burning.

\section{References}

Aikin, A. C., C. Gallagher, C. Spicer, and M. Holdren, Measurement of methane and other light hydrocarbons in the troposphere and lower stratosphere, J. Geophys. Res., 92, 3135-3138, 1987.

Altshuller, A. P., Review: Natural volatile organic substances and their effect on air quality in the United States, Atmos. Environ., $17,2131-2165,1983$.

Atkinson, R., D. L. Baulch, R. A. Cox, R. F. Hampson Jr., J. A. Kerr, and J. Troe, Evaluated kinetic and photochemical data for atmospheric chemistry, Supplement IV, JUPAC subcommittee on gas kinetic data evaluation for atmospheric chemistry, J. Phys. Chem. Ref. Data, 21, 1125-1568, 1992.

Blake, D. R., and F. S. Rowland, Global atmospheric concentration and source strength of ethane, Nature, 321, 231-233, 1986.

Blake, D. R., D. Hurst, T. W. Smith Jr., W. J. Whipple, T. J. Chen, N. J. Blake, and F. S. Rowland, Summertime measurements of selected nonmethane hydrocarbons in the Arctic and subarctic during the 1988 Arctic Boundary Layer Expedition (ABLE 3A), $J$. Geophys. Res., 97, 16,559-16,588, 1992.

Blake, D. R., T. W. Smith Jr., T.-Y. Chen, W. J. Whipple, and F. S. Rowland, Effects of biomass burning on summertime nonmethane hydrocarbon concentrations in the Canadian wetlands, J. Geophys. Res., 99, 1699-1719, 1994.

Blake, D. R., T.-Y. Chen, T. W. Smith Jr., C. J.-L. Wang, O. P. Wingenter, F. S. Rowland, and E. W. Mayer, Three-dimensional distribution of NMHCs and halocarbons over the northwestern Pacific during the 1991 Pacific Exploratory Mission (PEM-West A), J. Geophys. Res., in press, 1995. 
Bonsang, B., and G. Lambert, Nonmethane hydrocarbons in an oceanic atmosphere, J. Atmos. Chem., 2, 257-271, 1985.

Bonsang, B., M. Kanakidou, G. Lambert, and P. Monfray, The marine source of $\mathrm{C}_{2}-\mathrm{C}_{5}$ aliphatic hydrocarbons, J. Atmos. Chem., 6, 3-20, 1988.

Bonsang, B., M. Kanakidou, and G. Lambert, NMHC in marine atmosphere: Preliminary results of monitoring at Amsterdam Island, J. Atmos. Chem., 11, 169-178, 1990.

Bonsang, B., D. Martin, G. Lambert, M. Kanakidou, J. C. Le Roulley, and G. Sennequier, Vertical distribution of nonmethane hydrocarbons in the remote marine boundary layer, J. Geophys. Res., 96, 7313-7324, 1991.

Bonsang, B., C. Boissard, M. F. Le Cloarec, J. Rudolph, and J. P. Lacaux, Methane, carbon monoxide and light nonmethane hydrocarbon emissions from African savanna burnings during the FOS/DECAFE experiment, J. Atmos. Chem., in press, 1994.

Brasseur, G., M. H. Hitchman, S. Walters, M. Dymek, E. Falise, and $M$. Pirre, An interactive chemical dynamical radiative twodimensional model of the middle atmosphere, J. Geophys. Res., 95, 5639-5655, 1990.

Bucher, J. B., Emissions of volatiles from plants under air pollution stress, in Proceedings of the International Symposium on Gaseous Air Pollution and Plant Metabolism, pp. 399-412, Butterworths, London, 1984

Carsey, T. P., Nonmethane hydrocarbons in the remote marine troposphere: Results of an intercomparison exercise, Eos Trans. $A G U, 68,1220,1987$.

Cronn, D., and E. Robinson, Tropospheric and lower stratospheric vertical profiles of ethane and acetylene, Geophys. Res. Lett., 6 , 641-644, 1979.

Craig, E., D. Picard, P. Pope, and A. Rosland, Methane emissions from oil and gas, in Proceedings of the International IPCC Workshop on Methane and Nitrous Oxide, edited by A. R. van Amstel, pp. 41-61, Bilthoven, Netherlands, 1993.

Crutzen, P. J., and M. O. Andreae, Biomass burning in the tropics: Impact on atmospheric chemistry and biogeochemical cycles, Science, 250, 1669-1678, 1990.

Czeplak, G., and C. Junge, Study of interhemispheric exchange in the troposphere by a diffusion model, Adv. Geophys., 18(B), 57-72, 1974.

Donahue, N. M., and R. G. Prinn, In situ nonmethane hydrocarbon measurements on SAGA 3, J. Geophys. Res., 98, 16,915-16,932, 1993.

Ehhalt, D. H., Concentrations and distributions of atmospheric trace gases, Ber. Bunsenges. Phys. Chem., 96, 229-240, 1992.

Ehhalt, D. H., and J. Rudolph, On the importance of light hydrocarbons in multiphase atmospheric systems, Ber. Kernforschungsanlage Jülich, JÜL-1942, 20-28, 1984.

Ehhalt, D. H., J. Rudolph, F. X. Meixner, and U. Schmidt, Measurements of selected $\mathrm{C}_{2}-\mathrm{C}_{5}$ hydrocarbons in the background troposphere: Vertical and latitudinal variations, J. Atmos. Chem., 3, 29-52, 1985.

Ehhalt, D. H., J. Rudolph, and U. Schmidt, On the importance of light hydrocarbons in multiphase atmospheric systems, in Chemistry of Multiphase Systems, edited by W. Jaenicke, pp. 321, Springer-Verlag, New York, 1986.

Ehhalt, D. H., U. Schmidt, R. Zander, P. Demoulin, and C. Rinsland, Seasonal cycle and secular trend of the total column abundance of ethane above the Jungfraujoch, J. Geophys. Res., 96, 4985-4994, 1991.

Greenberg, J. P., and P. R. Zimmerman, Nonmethane hydrocarbons in the remote troposphere, J. Geophys. Res., 89, 4767-4778, 1984.

Greenberg, J. P., P. R. Zimmerman, and P. Haagenson, Tropospheric hydrocarbon and CO profiles over the U.S. West Coast and Alaska, J. Geophys. Res., 95, 14,015-14,026, 1990.

Greenberg, J. P., P. R. Zimmerman, W. F. Pollock, R. A. Lueb, and L. E. Heidt, Diurnal variability of atmospheric methane, nonmethane hydrocarbons, and carbon monoxide at Mauna Loa, $J$. Geophys. Res., 97, 10,395-10,414, 1992.

Hahn, J., R. Steinbrecher, and K. Stahl, Study of the emission of low molecular weight organic compounds of various plants, in Eurotrac Annual Report, 4, BIATEX, pp. 180-185, Int. Sci. Secr., Garmisch-Partenkirchen, Germany, 1991.

Hahn, J., R. Steinbrecher, and J. Slemr, Study of the emission of low molecular weight organic compounds of various plants, in
Eurotrac Annual Report, 4, BIATEX, pp. 230-235, GarmischPartenkirchen, Germany, 1992.

Hansen, J., G. Russell, D. Rind, P. Stone, A. Lacis, S. Lebedeff, R. Ruedy, and L. Travis, Efficient three-dimensional global models for climate studies: Models I and II, Mon. Weather Rev., 111, $609-662,1983$

Hough, A. M., Development of a two-dimensional global tropospheric model: Model chemistry, J. Geophys. Res., 96, 7325$7362,1991$.

Hov, O., S. A. Penkett, I. S. A. Isaksen, and A. Semb, Organic gases in the Norwegian Arctic, Geophys. Res. Lett., 11, 425-428, 1984.

Hov, O., N. Schmidtbauer, and M. Oehme, Light hydrocarbons in the Norwegian Arctic, Atmos. Environ., 23, 2471-2482, 1989.

Isaksen, I. S. A., O. Hov, S. A. Penkett, and A. Semb, Model analysis of the measured concentration of organic gases in the Norwegian Arctic, J. Atmos. Chem., 3, 3-27, 1985.

Jobson, B. T., Z. Wu, H. Niki, and L. A. Barrie, Seasonal trends of isoprene, $\mathrm{C}_{2}-\mathrm{C}_{5}$ alkanes and acetylene at a remote boreal site in Canada, J. Geophys. Res., 99, 1589-1599, 1994.

Johnson, J. E., M. Koropalov, K. E. Pickering, A. M. Thompson, N. Bond, and J. W. Elkins, Third Soviet-American Gas and Aerosol experiment (SAGA 3): Overview and meteorological and oceanographic conditions, J. Geophys. Res., 98, 16,893-16,908, 1993.

Kanakidou, M., H. B. Singh, K. M. Valentin, and P. J. Crutzen, A Two-dimensional study of ethane and propane oxidation in the troposphere, J. Geophys. Res., 96, 15,395-15,413, 1991.

Konze, J. R., and F. E. Elstner, Ethane and ethylene formation by Mitochondria as indicators of aerobic lipid degradation in response to wounding plant tissue, Biochim. Biophys. Acta, 528, 213-221, 1978.

Koppmann, R., F. J. Johnen, C. Plass, and J. Rudolph, The latitudinal distribution of light non-methane hydrocarbons over the mid-Atlantic between $40^{\circ} \mathrm{N}$ and $30^{\circ} \mathrm{S}$, in Proceedings of the 5 th European Symposium on Physico-Chemical Behaviour of Atmospheric Pollutants, edited by G. Restelli and G. Angeletti, pp. 657-662, Kluwer Academic, Norwell, Mass., 1990.

Koppmann, R., R. Bauer, F. J. Johnen, C. Plass-Dülmer, and J. Rudolph, The distribution of light nonmethane hydrocarbons over the mid-Atlantic: Results of the Polarstern cruise ANT VII/1, $J$. Atmos. Chem., 15, 215-234, 1992.

Lelieveld, J., and P. J. Crutzen, Methane emissions into the atmosphere, An overview, in Proceedings of the International IPCC Workshop on Methane and Nitrous Oxide, edited by A. R. van Amstel, pp. 17-25, Bilthoven, Netherlands, 1993.

Lightman, P., A. S. Kallend, A. R. W. Marsh, B. M. R. Jones, and S. A. Penkett, Seasonal variations of hydrocarbons in the free troposphere at mid-latitudes, Tellus, 42(B), 408-422, 1990.

Lindskog, A., and J. Moldanova, The influence of the origin, season and time of the day on the distribution of individual NMHC measured at Rörvik, Sweden, Atmos. Environ., 28, 2383-2398, 1994.

Mayrsohn, H., and J. H. Crabtree, Source reconciliation of atmospheric hydrocarbons, Atmos. Environ., 10, 137-143, 1976.

Nelson, P. F., S. M. Quigley, and M. Y. Smith, Sources of atmospheric hydrocarbons in Sydney: A quantitative determination using a source reconciliation technique, Atmos. Environ., 17. 439-449, 1983.

Penkett, S. A., Non-methane organics in the remote troposphere, in Atmospheric Chemistry, edited by E. D. Goldberg, pp. 329-355, Springer-Verlag, New York, 1982.

Photochemical Oxidants Review Group (PORG), United Kingdom, interim report, Dep. of the Environ., Harwell, U. K., 1987.

Plass, C., F. J. Johnen, R. Koppmann, and J. Rudolph, The latitudinal distribution of NMHC in the Atlantic and their fluxes into the atmosphere, in Proceedings of the $5^{\text {th }}$ European Symposium on Physico-Chemical Behaviour of Atmospheric Pollutants, edited by G. Restelli and G. Angeletti, pp. 663-668, Kluwer Academic, Norwell, Mass., 1990.

Plass-Dülmer, C., R. Koppmann, and J. Rudolph, Light hydrocarbons in the surface water of the mid-Atlantic, J. Atmos. Chem., 15, 235-251, 1992.

Plass-Dülmer, C., R. Koppmann, F. J. Johnen, J. Rudolph, and H. Kuosa, Emissions of light nonmethane hydrocarbons from the Atlantic into the atmosphere, Global Biogeochem. Cycles, 7, 211-228, 1993.

Plass-Dülmer, C., R. Koppmann, M. Ratte, and J. Rudolph, Light 
nonmethane hydrocarbons in seawater: An overview, Global Biogeochem. Cycles, in press, 1995.

Prinn, R., P. Simmonds, R. Rasmussen, R. Rosen, F. Alyea, C. Cardelino, A. Crawford, D. Cunnold, P. Fraser, and J. Lovelock, The atmospheric lifetime experiment, 1, Introduction, Instrumentation and overview, J. Geophys. Res., 88, 8352-8367, 1983.

Prinn, R., D. Cunnold, R. Rasmussen, P. Simmonds, F. Alyea, A. Crawford, P. Fraser, and R. Rosen, Atmospheric trends in methylchloroform and the global average for the hydroxyl radical, Science, 238, 945-950, 1987.

Rasmussen, R. A., and M. A. K. Khalil, Latitudinal distributions of trace gases in and above the boundary layer, Chemosphere, 11, $227-235,1982$

Kasmussen, R. A., and M. A. K. Khalil, Altitudinal and temporal variations of hydrocarbons and other tracers of Arctic haze, Geophys. Res. Lett., 10, 144-147, 1983.

Ratte, M., C. Plass-Dülmer, R. Koppmann, and J. Rudolph, Biological, chemical and physical parameters affecting the concentration of light hydrocarbons in sea water, Implications for the NMHC production mechanism, Tellus Ser. B, in press, 1995

Rinsland, C. P., R. Zander, C. B. Farmer, R. H. Norton, and J. M. Russel III, Concentrations of ethane $\left(\mathrm{C}_{2} \mathrm{H}_{6}\right)$ in the lower stratosphere and upper troposphere and acetylene $\left(\mathrm{C}_{2} \mathrm{H}_{2}\right)$ in the upper troposphere deduced from atmospheric trace molecule spectroscopy/Spacelab spectra, J. Geophys. Res., 92, 11,951-11,964, 1987.

Rudolph, J., Two-dimensional distribution of light hydrocarbons: Results from the STRATOZ III experiment, J. Geophys. Res., 93 8367-8377, 1988.

Rudolph, J., and D. H. Ehhalt, Measurements of $\mathrm{C}_{2}-\mathrm{C}_{5}$ hydrocarbons over the North Atlantic, J. Geophys. Res., 86, 11,959$11,964,1981$.

Rudolph, J., and C. Jebsen, The use of photo ionisation, flame ionisation and electron capture detectors in series for the determination of low molecular weight trace components in the non-urban atmosphere, Int. J. Environ. Anal. Chem., 13, 129-139, 1983.

Rudolph, J., and F. J. Johnen, Measurements of light atmospheric hydrocarbons over the Atlantic in regions of low biological activity, J. Geophys. Res., 95, 20,583-20,591, 1990.

Rudolph, J., and A. Khedim, Hydrocarbons in the non-urban atmosphere: Analysis, ambient concentrations and impact on the chemistry of the atmosphere, Int. J. Environ. Anal. Chem., 20, 265-282, 1985.

Rudolph, J., and R. Koppmann, Sources and atmospheric distribution of light hydrocarbons, in Proceedings of the $28^{\text {th }}$ Astrophysical Colloquium on Our Changing Atmosphere, edited by P. J. Crutzen, J.-C. Gerard, and R. Zander, pp. 435-447, 1990.

Rudolph, J., D. H. Ehhalt, and G. Gravenhorst, Recent measurements of light hydrocarbons in remote areas, in Proceedings of the 1st European Symposium on Physico-Chemical Behaviour of Atmospheric Pollutants, edited by B. Versino and G. Ott, pp. 41-51, 1979.

Rudolph, J., D. H. Ehhalt, and A. Tönnißen, Measurements of ethane and propane in the troposphere and stratosphere, in Proc. Int. Ozone Symp., vol. 2, 809-815, 1980.

Rudolph, J., D. H. Ehhalt, and A. Tönnißen, Vertical profiles of ethane and propane in the stratosphere, J. Geophys. Res., 86, 7267-7272, 1981a.

Rudolph, J., D. H. Ehhalt, A. Khedim, and C. Jebsen, Determination of $\mathrm{C}_{2}-\mathrm{C}_{5}$ hydrocarbons in the atmosphere at low parts per $10^{9}$ to high parts per $10^{12}$ levels, J. Chromatogr., 217, 301-310, $1981 \mathrm{~b}$.

Rudolph, J., D. H. Ehhalt, A. Khedim, and C. Jebsen, Latitudinal profiles of some $\mathrm{C}_{2}-\mathrm{C}_{5}$ hydrocarbons in the clean troposphere over the Atlantic (preprint), in Proceedings of the 2nd Symposium on Composition of the Nonurban Troposphere, pp. 284-286, American Meteorological Society, Boston, Mass., 1982a.

Rudolph, J., D. H. Ehhalt, U. Schmidt, and A. Khedim, Vertical distribution of some $\mathrm{C}_{2}-\mathrm{C}_{5}$ hydrocarbons in the nonurban troposphere (preprint), in Proceedings of the 2nd Symposium on Composition of the Nonurban Troposphere, pp. 56-59, American Meteorological Society, Boston, Mass., 1982b.

Rudolph, J., C. Jebsen, A. Khedim, and F. J. Johnen, Measurements of the latitudinal distribution of light hydrocarbons and halocarbons over the Atlantic, in Proceedings of the 3rd European Symposium on Physico-Chemical Behaviour of Atmospheric Pollutants, edited by B. Versino and G. Angeletti, pp. 492-414, D. Reidel, Norwell, Mass., 1984.
Rudolph, J., F. J. Johnen, and A. Khedim, Problems connected with the analysis of hydrocarbons and halocarbons in the non-urban atmosphere, Int. J. Environ. Anal. Chem., 27, 97-122, 1986.

Rudolph, J., A. Khedim, and D. Wagenbach, The seasonal variation of light nonmethane hydrocarbons in the Antarctic troposphere, J. Geophys. Res., 94, 13,039-13,044, 1989a.

Rudolph, J., F. J. Johnen, A. Khedim, and G. Pilwat, The use of automated "on line" gaschromatography for the monitoring of organic trace gases in the atmosphere at low levels, Int. J. Environ. Anal. Chem., 38, 143, 1989b.

Rudolph, J., K. P. Müller, and R. Koppmann, Sampling of organic volatiles in the atmosphere at moderate and low pollution levels, Anal. Chim. Acta, 236, 197-211, 1990.

Rudolph, J., A. Khedim, T. Clarkson, and D. Wagenbach, Long term measurements of light alkanes and acetylene in the Antarctic troposphere, Tellus, 44(B), 252-261, 1992a.

Rudolph, J., A. Khedim, and B. Bonsang, Light hydrocarbons in the tropospheric boundary layer over tropical Africa, J. Geophys. Res., 97, 6181-6186, 1992b.

Rudolph, J., A. Khedim, R. Koppmann, G. Helas, and B. Bonsang, Field study of the halocarbon emissions from biomass burning in Africa, in Proceedings of the $6^{\text {th }}$ European Symposium on Physico-Chemical Behaviour of Atmospheric Pollutants, edited by G. Angeletti and G. Restelli, pp. 424-430, Brussels, 1994.

Rudolph, J., A. Khedim, R. Koppmann, and B. Bonsang, Field study of the emissions of methyl chloride and other halocarbons from biomass burning in western Africa, J. Atmos. Chem., in press, 1995.

Schmitt, R., Ermittlung von Basispegeln ausgewählter Luftverunreinigungen, final report, Luftreinhaltung Forschungsprojekt 10402577 des Bundesmin. für Forsch. und Technol., Germany, April 1990.

Singh, H. B., and L. J. Salas, Measurements of selected light hydrocarbons over the Pacific Ocean, Geophys. Res. Lett., 9, 842-845, 1982

Singh, H. B., and P. R. Zimmerman, Atmospheric distribution and sources of nonmethane hydrocarbons, Adv. in Environ. Sci. Technol., 24, 177-235, 1990.

Singh, H. B., W. Viezee, and L. J. Salas, Measurements of selected $\mathrm{C}_{2}-\mathrm{C}_{5}$ hydrocarbons in the troposphere: Latitudinal, vertical, and temporal variations, J. Geophys. Res., 93, 15,861-15,878, 1988.

Taylor, J. A., G. P. Brasseur, P. R. Zimmerman, and R. J. Cicerone, A study of the sources and sinks of methane and methyl chloroform using a global three-dimensional Lagrangian tropospheric tracer transport model, J. Geophys. Res., 96, 3013-3044, 1991.

Tille, K. J. W., M. Savelsberg, and K. Bächmann, Airbome measurements of nonmethane hydrocarbons over western Europe: Vertical distributions, seasonal cycles of mixing ratios and source strength, Atmos. Environ., 19, 1751-1760, 1985.

Tyler, S. C., D. R. Blake, and F. S. Rowland, ${ }^{13} \mathrm{C} /{ }^{12} \mathrm{C}$ Ratio in methane from flooded Amazon forest, J. Geophys. Res., 92, 1044-1048, 1987.

Van Clemput, O., and A. Vermoesen, Emission of gaseous hydrocarbons and $\mathrm{NH}_{3}$ out of soils, in Eurotrac Annual Report, 4, BIATEX, pp. 174-179, Garmisch-Partenkirchen, Germany, 1991.

Van Clemput, O., A. S. El-Sebaay, and L. Baert, Production of gaseous hydrocarbons in soils, in Proceedings of the 2nd European Symposium on Physico-Chemical Behaviour of Atmospheric Pollutants, edited by B. Versino and H. Ott, pp. 349-355, D. Reidel, Norwell, Mass., 1981.

Volz, A., D. H. Ehhalt, and R. D. Derwent, Seasonal and Latitudinal Variation of ${ }^{14} \mathrm{CO}$ and the tropospheric concentration of $\mathrm{OH}$ radicals, J. Geophys. Res., 86, 5163-5171, 1981.

Warneck, P., Chemistry of the Natural Atmosphere, pp. 27-37 and pp. 235-236, Academic, San Diego, Calif., 1988.

Whiticar, M. J., A geochemical perspective of natural gas and atmospheric methane, Org. Geochem., 16, 531-547, 1990.

Zimmerman, P. R., Determination of emission rates of hydrocarbons from indigenous species of vegetation in the Tampa/St. Petersburg, Florida area, EPA Rep. 904/9-77-028, Environ. Prot. Agency, Washington, D. C., 1979.

J. Rudolph, Inst. für Atmosphärische Chemie, Forschungszentrum Jülich, GMBH D-52425 Jülich, Germany.

(Received August 31, 1994; revised February 21, 1995; accepted February 21, 1995.) 